\title{
Modeling plankton ecosystem functioning and nitrogen fluxes in the oligotrophic waters of the Beaufort Sea, Arctic Ocean: a focus on light-driven processes
}

\author{
V. Le Fouest ${ }^{1}$, B. Zakardjian ${ }^{2,4}$, H. Xie ${ }^{3}$, P. Raimbault ${ }^{2,4}$, F. Joux ${ }^{5}$, and M. Babin 6 \\ ${ }^{1}$ Laboratoire d'Océanographie de Villefranche, BP 8, CNRS UMR7093 \& Université Pierre et Marie Curie, 06238 \\ Villefranche-sur-Mer Cedex, France \\ ${ }^{2}$ Université du Sud Toulon-Var, CNRS/INSU, IRD, Mediterranean Institute of Oceanography (MIO), UM 110, 83957 La \\ Garde, France \\ ${ }^{3}$ Institut des sciences de la mer de Rimouski, Université du Québec à Rimouski, 310, allée des Ursulines, C.P. 3300 Rimouski \\ (Quebec) G5L 3A1, Canada \\ ${ }^{4}$ Aix-Marseille Université, CNRS/INSU, IRD, Mediterranean Institute of Oceanography (MIO), UM 110, 13288 Marseille, \\ France \\ ${ }^{5}$ Laboratoire d'Océanographie Microbienne, CNRS UMR7621 \& Université Pierre et Marie Curie, 66650 Banyuls-sur-Mer, \\ France \\ ${ }^{6}$ Takuvik Joint International Laboratory, Université Laval (Canada) \& Centre National de la Recherche Scientifique (France), \\ Département de Biologie, 1045, Avenue de la Médecine, Quebec (Quebec), G1V 0A6, Canada
}

Correspondence to: V. Le Fouest (lefouest@obs-vlfr.fr)

Received: 28 September 2012 - Published in Biogeosciences Discuss.: 24 October 2012

Revised: 7 June 2013 - Accepted: 13 June 2013 - Published: 15 July 2013

\begin{abstract}
The Arctic Ocean (AO) undergoes profound changes of its physical and biotic environments due to climate change. In some areas of the Beaufort Sea, the stronger haline stratification observed in summer alters the plankton ecosystem structure, functioning and productivity, promoting oligotrophy. A one-dimension (1-D) physical-biological coupled model based on the large multiparametric database of the Malina project in the Beaufort Sea was used (i) to infer the plankton ecosystem functioning and related nitrogen fluxes and (ii) to assess the model sensitivity to key light-driven processes involved in nutrient recycling and phytoplankton growth. The coupled model suggested that ammonium photochemically produced from photosensitive dissolved organic nitrogen (i.e., photoammonification process) was a necessary nitrogen source to achieve the observed levels of microbial biomass and production. Photoammonification directly and indirectly (by stimulating the microbial food web activity) contributed to $70 \%$ and $18.5 \%$ of the 0 $10 \mathrm{~m}$ and whole water column, respectively, simulated primary production (respectively $66 \%$ and $16 \%$ for the bacte-
\end{abstract}

rial production). The model also suggested that variable carbon to chlorophyll ratios were required to simulate the observed herbivorous versus microbial food web competition and realistic nitrogen fluxes in the Beaufort Sea oligotrophic waters. In face of accelerating Arctic warming, more attention should be paid in the future to the mechanistic processes involved in food webs and functional group competition, nutrient recycling and primary production in poorly productive waters of the $\mathrm{AO}$, as they are expected to expand rapidly.

\section{Introduction}

The Arctic Ocean (AO) undergoes profound changes of its physical and biotic environments due to climate change. Overall net primary production (PP) is shown to have increased in the last decades (Bélanger et al., 2012; Arrigo and Djiken, 2011) and is expected to follow this trend in the future (Slagstad et al., 2011). Nevertheless, the PP response is not the same everywhere in the AO, with regions showing 
stable or even decreasing PP (Arrigo et al., 2011; Slagstad et al., 2011). In the Hudson Bay, Foxe Basin, Baffin Sea, off the coasts of Greenland, in the Kara Sea and around Novaya Zemlya, earlier blooms are observed in response to earlier light exposure caused by sea ice retreat (Kahru et al., 2011). In some areas of the Beaufort Sea, the stronger haline stratification recently observed mediates the growing contribution of small phytoplankton cells to the planktonic community in summer (Li et al., 2009) suggesting oligotrophy is expanding in this part of the AO. In the Barents Sea, the $40 \%$ projected widening of the productive time period will probably allow heterotrophic organisms to optimize grazing through growth and reproduction on phytoplankton, and hence alter the carbon quality and quantity exported to the benthic realm (Wassmann and Reigstad, 2011). In this context of accelerating Arctic sea ice decline (Comiso et al., 2008), a better knowledge of the mechanistic processes and biogenic fluxes mediating PP is required, with particular attention paid to the oligotrophic season when biogenic fluxes are complex and so far are poorly quantified.

In the AO, more than $80 \%$ of the PP takes place in shelf seas (Sakshaug, 2004). The Beaufort Sea exhibits the lowest annual production rate (8 Tg C; Sakshaug, 2004) with respect to its surface area $\left(\sim 476000 \mathrm{~km}^{2}\right)$, which makes it the most oligotrophic shelf sea in summer (Ardyna et al., 2013). After the bloom occurring in June, a deep chlorophyll (Chl) maximum (DCM) forms as a result of relatively low nitrate concentrations in the surface layer at the end of spring (Tremblay et al., 2008). Over the growth season, the DCM progressively lowers the nitracline down to $60 \mathrm{~m}$ depth, where light becomes the limiting factor (Martin et al., 2010). On the slope of the Mackenzie Shelf, where waters were amongst the most oligotrophic sampled during the Malina cruise (Tremblay et al., 2013), picoplankton (Micromonas ecotype) and phytoplankton $<5 \mu \mathrm{m}$ dominated respectively the surface and DCM autotrophic community (Balzano et al., 2012; Claustre and Ras, unpublished data) whose role is central in mediating carbon fluxes in summer (Li et al., 2009).

The ability of coupled physical-biogeochemical models applied to the AO to simulate realistic plankton dynamics and production rates relies on both the simulated physics (e.g., Popova et al., 2010) and elemental biogeochemical fluxes (e.g., Le Fouest et al., 2011). In summer, nutrients within the upper mixed layer are mostly issued from the remineralization of freshly produced organic matter. Hence biogeochemical equations driving the simulated elemental fluxes between the ecosystem compartments play a pivotal role. The representation in models of key biogeochemical processes and their comparison with measurements is generally limited in the $\mathrm{AO}$ by the lack of joint multiparametric measurements, especially nutrient turnover rates and lightdriven processes. Such measurements were done in the Beaufort Sea during the Malina project (http://malina.obs-vlfr.fr) in summer 2009 (18 July-24 August), providing an opportunity to improve plankton ecosystem models. A physical- biological coupled model of the water column was set up based on the extensive use of physical and biogeochemical variables and rates measured during the Malina cruise. Steady-state runs were analyzed to budget the system and to gain a better understanding of the plankton ecosystem functioning in the most oligotrophic shelf waters of the AO. The objectives of this study are, on one hand, to infer the functioning and nitrogen fluxes within the summer plankton ecosystem and, on the other hand, to assess the model sensitivity to key light-associated processes involved in nutrient recycling and phytoplankton growth.

\section{Material and methods}

\subsection{Observations}

The large multiparametric dataset of physical, chemical and biological measurements collected during the Malina cruise (18 July-24 August, 2009) in the Beaufort Sea was used (i) to initiate and constrain the model runs, (ii) to set parameters and transfer functions and (iii) to compare with the model outputs. We provide here a summary of the data used along with their respective reference in the Malina special issue, where the detailed methodology for each measurement can be found. Measurements were taken in the Beaufort Sea at the continental edge slope and ice-edge station $345\left(71.33^{\circ} \mathrm{N}, 132.56^{\circ} \mathrm{W}\right)$, sampled on 14-16 August, 2009 (Fig. 1). Temperature, salinity and fluorescence were measured using a conductivity-temperature-depth (CTD) sensor. Temperature and salinity data were used to compute potential density, which were in turn used to compute Brunt-Väisälä frequencies $(N)$. The latter were calculated in a leap-frog fashion, with the potential density from the previous and following depths (i.e., $N$ at $5 \mathrm{~m}$ is computed with the data at $4 \mathrm{~m}$ and $6 \mathrm{~m}$ ) (Gratton and Prieur, unpublished data). Surface and vertical profiles of downwelling photosynthetic available radiation (PAR) were respectively measured by an on-deck sensor and a Compact-Optical Profiling System (C-OPS) profiler (Hooker et al., 2012). With respect to photosynthesis parameters, photosynthesis initial slopes $(\alpha)$ and light saturation parameters $\left(E_{k}\right)$ were taken from Huot et al. (2013). Ammonium concentrations $\left(\mathrm{NH}_{4}\right)$ were determined on board by fluorometer according to Holmes et al. (1999). Nitrate concentrations $\left(\mathrm{NO}_{3}\right)$ were quantified in the laboratory using an automatic colorimetric procedure (Raimbault et al., 1990). For both nutrients, the coefficient of variation (CV) was $5 \%$. Detection limits were $3 \mu \mathrm{mol} \mathrm{m}^{-3}$ and $5 \mu \mathrm{mol} \mathrm{m} \mathrm{m}^{-3}$ for $\mathrm{NH}_{4}$ and $\mathrm{NO}_{3}$, respectively. Rates of primary production, $\mathrm{NH}_{4}$ and $\mathrm{NO}_{3}$ uptake (CV 20-25\%), and $\mathrm{NH}_{4}$ regeneration and nitrification (CV 20-25\%) were measured using a dual ${ }^{13} \mathrm{C} /{ }^{15} \mathrm{~N}$ isotopic technique (Raimbault et al., 1999a) applied during a 24-hour in situ incubation. Size-fractionated Chl concentrations measured during the Malina cruise following the methodology described in Ardyna et al. (2011) 


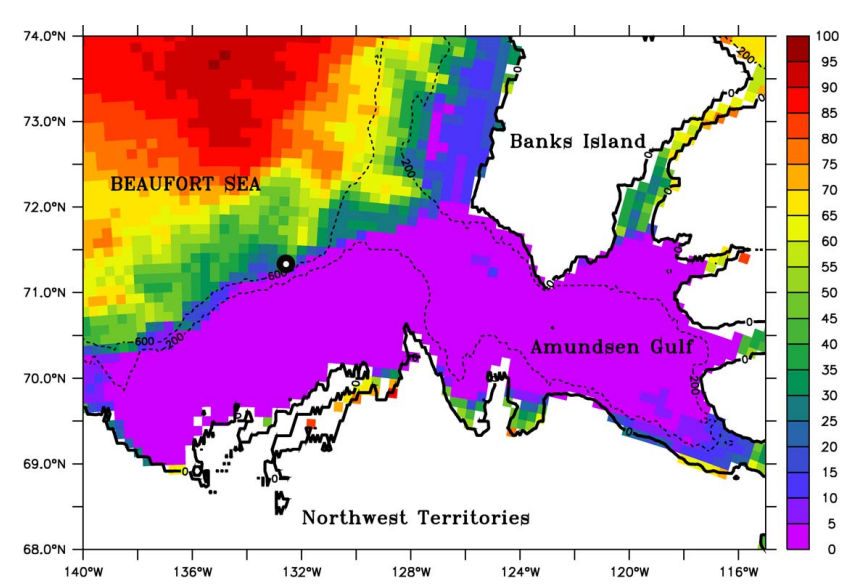

Fig. 1. Mean remotely sensed sea ice concentration (\%; calculated from Special Sensor Microwave Imager (SSM/I) data from http://cersat.ifremer.fr) for the 14-16 August 2009 sampling period. Station 345 is indicated by a white point within a larger black one. The full and dashed black lines indicate the land contour and the $200 \mathrm{~m}$ and $600 \mathrm{~m}$ isobaths, respectively. Land appears in white.

were used (S. Bélanger, unpublished data) (CV 10\%). Particulate organic nitrogen (PON) and carbon (POC) were simultaneously determined by a wet-oxidation method using sealed vials (Raimbault et al., 1999b) (CV 10\%). POC measurements were used to compute POC: Chl ratios. Bacterial biomasses were derived from the product of the measured cell counts with the measured mean carbon content per cell (15.2 fg; Ortega-Retuerta et al., 2012a) (CV 10\%). Production rates estimated in pmol Leu $\mathrm{L}^{-1} \mathrm{~h}^{-1}$ were converted into carbon equivalent using a conversion factor of $1.5 \mathrm{~kg} \mathrm{C}$ $(\mathrm{mol} \mathrm{Leu})^{-1}$ (Kirchman et al., 2009). Copepod biomasses were obtained from Underwater Video Profiler data converted into carbon units (Forest et al., 2012) and then into nitrogen using a molar $\mathrm{C}: \mathrm{N}$ ratio of 8.1 (Forest et al., 2010).

\subsection{The coupled physical-biological model}

Based on the Malina cruise dataset, a mass-based $\left(\mathrm{mmolN} \mathrm{m}{ }^{-3}\right)$ plankton ecosystem model was coupled to a vertically resolved one-dimension (1-D) physical model to compute biogeochemical concentrations and fluxes on the slope of the Mackenzie Shelf at the ice-edge station 345 sampled on 14-16 August, 2009 (Fig. 1). This station was chosen with regard to the very oligotrophic conditions observed and the extensive multiparametric dataset available. The coupled model extends vertically to $200 \mathrm{~m}$ depth with constant $1 \mathrm{~m}$ layers. It is constrained by a stationary field of vertical diffusion coefficient $\left(K_{z}, \mathrm{~m}^{2} \mathrm{~d}^{-1}\right)$ and a diurnal cycle of surface photosynthetic available radiation (PAR, $\mathrm{E} \mathrm{m}^{-2} \mathrm{~d}^{-1}$ ) $\left(E_{0}\right) . K_{z}$ was computed from a mean Brunt-Väisälä $(N)$ profile derived from measurements collected on 14-16 August and turbulent kinetic energy turbulent dissipation rates $\left(\varepsilon=5 \times 10^{-8}\right.$ to $\left.5 \times 10^{-7} \mathrm{~m}^{2} \mathrm{~s}^{-3}\right)$ using the Osborn (1980)
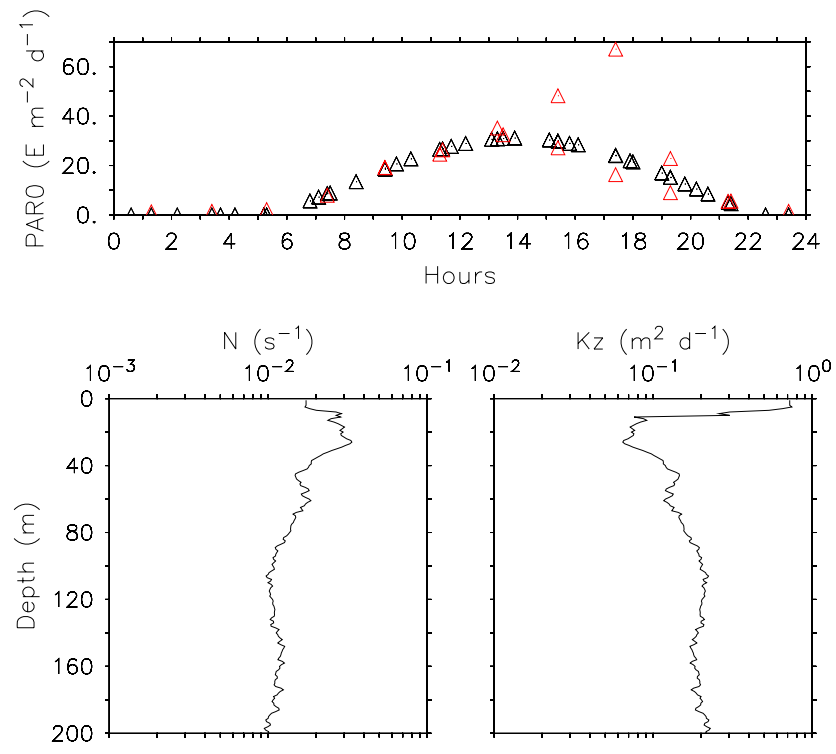

Fig. 2. Measured (14-15 August, 2009, red triangles) and fittedfrom-data (black triangles) surface PAR (PAR0, upper panel), 4-day (14-16 August, 2009) averaged profile of measured Brunt-Väisälä frequency $(N$, lower left panel) and derived profile of eddy diffusion coefficient $\left(K_{z}\right.$, lower right panel).

formulation $\left(K_{z}=0.25 \frac{\varepsilon}{N^{2}}\right)$. A diurnal cycle of $E_{0}$ was obtained by fitting a cosine function to $E_{0}$ on-deck measurements (14-15 August) at the same station. Both physical forcing fields are shown in Fig. 2.

The plankton ecosystem model (Fig. 3), fully detailed in the Appendix, is of moderate complexity and includes 10 compartments chosen according to the ecosystem structure observed during the cruise and measurements available. Phytoplankton is size-fractionated into large $(>5 \mu \mathrm{m})$ and small $(<5 \mu \mathrm{m})$ phytoplankton (LP and SP, respectively). The two zooplankton compartments represent large (LZ, mainly copepods) and small (SZ, protozooplankton) organisms. Bacteria are explicitly represented following the model of Fasham et al. (1990). Available nutrients for phytoplankton growth are nitrate $\left(\mathrm{NO}_{3}\right)$ and ammonium $\left(\mathrm{NH}_{4}\right)$. Detrital (i.e., produced by the ecosystem model compartments) particulate and dissolved organic nitrogen (dPON and dDONl, respectively) close the nitrogen cycle. The standing stock of potentially photosensitive DON (DONp) is photochemically transformed into $\mathrm{NH}_{4}$ within the first $10 \mathrm{~m}$ of the water column. LP and SP growth depends on light, $\mathrm{NO}_{3}$ and $\mathrm{NH}_{4}$ availability according to the Liebig's law of minimum. LZ graze on LP and SZ, whereas SZ graze on SP and bacteria. Fecal pellets and LP basal mortality fuel the dPON pool. The dDONl pool is made of unassimilated nitrogen resulting from SZ grazing (21\% of the total biomass grazed), SP and SZ basal mortality and dPON fragmentation. Bacterial release, LZ excretion and unassimilated nitrogen resulting from SZ grazing ( $49 \%$ of the total biomass grazed) are the sources of 


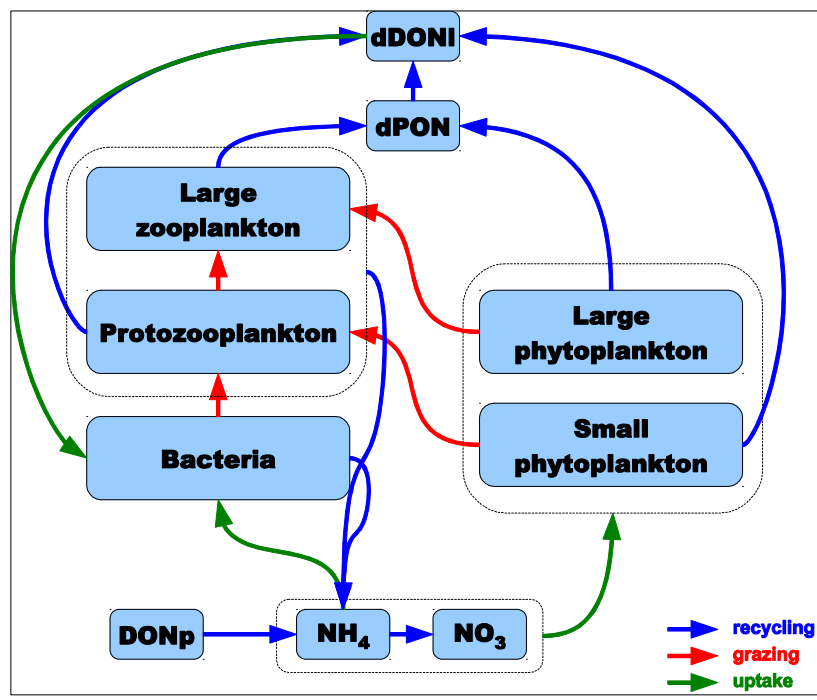

Fig. 3. Conceptual diagram of the plankton ecosystem model. The 10 state variables are nitrate $\left(\mathrm{NO}_{3}\right)$, ammonium $\left(\mathrm{NH}_{4}\right)$, large $(>5 \mu \mathrm{m})$ and small $(<5 \mu \mathrm{m})$ phytoplankton, copepods, protozooplankton, bacteria, detrital particulate and dissolved organic nitrogen (dPON and dDONl, respectively), and photosensitive dissolved organic nitrogen (DONp). Green, red and blue arrows represent nutrient uptake, grazing and nitrogen recycling, respectively.

$\mathrm{NH}_{4}$ in the model. $\mathrm{NH}_{4}$ is converted into $\mathrm{NO}_{3}$ through the nitrification process. Nitrogen is converted into carbon using the Redfield carbon to nitrogen $(\mathrm{C}: \mathrm{N})$ molar ratio $(106: 16$; Redfield et al., 1963) and into Chl using variable $\mathrm{C}: \mathrm{Chl}$ mass ratios computed according to a modified version of the phytoplankton photoacclimation model of Cloern et al. (1995).

Profiles of initial conditions were defined as the linear interpolation ( $1 \mathrm{~m}$ as in the model grid) of vertical distributions from bottle casts collected at station 345 (sampled depths are shown in Fig. 5). For $\mathrm{NO}_{3}$ and $\mathrm{NH}_{4}$, we used surface to $90 \mathrm{~m}$ deep (the maximum sampling depth at this station) concentrations averaged from 2 casts from 14 August. Below $90 \mathrm{~m}$ and to the end of the numerical vertical domain, we averaged concentrations $(0.02<\mathrm{CV}<0.04)$ from stations of the entire sampling grid for which nutrients were collected. For LP, we pooled together size-fractionated $\mathrm{Chl}>20 \mu \mathrm{m}$ (pore size $20 \mu \mathrm{m}$ ) and $\mathrm{Chl}>5 \mu \mathrm{m}$ (pore size $5 \mu \mathrm{m}$ ) measured on $15 \mathrm{Au}$ gust, whereas the Chl size fraction between $0.7 \mu \mathrm{m}$ and $5 \mu \mathrm{m}$ (pore size $0.7 \mu \mathrm{m}$ ) was used for SP. Below $90 \mathrm{~m}$, null concentrations were assigned based on CTD fluorescence profiles collected on 14-15 August. Profiles of Chl concentrations were converted into nitrogen units using the modified Cloern et al. (1985) model at time step 0 of the model run to initiate the LP and SP state variables. SZ initial concentrations in the model were obtained by subtracting the sum of vertically interpolated biomass measurements (15 August) of phytoplankton (LP and SP, see above) and bacteria in nitrogen unit from time coincident vertically interpolated bottle cast measurements of PON. DONp in the model results from the vertical interpolation of DON concentrations measured on 15 August. dDONl and dPON were assigned a priori a constant value of $0.001 \mathrm{mmol} \mathrm{N} \mathrm{m}^{-3}$ and $0.0002 \mathrm{mmol} \mathrm{N} \mathrm{m}^{-3}$, respectively, at each grid point of the vertical numerical domain. Vertical boundary conditions are no flux at the sea surface (Neumann condition with vertical derivatives set to zero for all variables) and constant concentrations (Dirichlet condition) at the bottom boundary. Constant concentrations at the bottom were calculated from the linear interpolation procedure.

The set of differential equations (Table 1) was solved in a discrete form (explicit Crank-Nicolson scheme derived from the control volume approach, see Roach, 1972) with Choleski's double scanning method (also called Thomas algorithm in Roach, 1972). The coupled model was run with an hourly time step. The time evolution of each of the 10 state variables $(C)$ is computed with the general partial differential equation as follows:

$\frac{\partial C}{\partial t}=\frac{\partial}{\partial z}\left[K_{z} \frac{\partial C}{\partial z}\right]+$ source terms - loss terms

where $t$ is time, $z$ is the vertical coordinate and $K_{z}$ is the vertical eddy diffusion coefficient.

\section{Results and discussion}

\subsection{Plankton ecosystem functioning and nitrogen fluxes}

A diurnal simulation repeated 1200 times was run so that the diffused state variables reached a near equilibrium state (Fig. 4) ("standard" run). Our steady-state approach was taken from the previous studies of Zakardjian and Prieur (1994, 1998). It aimed at using the best set of biological functions and parameters to get as close as possible from a theoretical equilibrium state of nitrogen fluxes between the biogeochemical compartments, independently of the preset initial conditions. The plankton ecosystem model tended towards near equilibrium given the imposed environmental conditions. The integration time required to reach such equilibrium in biogeochemical models is first dependant on vertical mixing and vertical velocities that constrain the timescale required for the numerical adjustment of the scalar gradients. Strong physical forcings (e.g., high turbulence or significant vertical velocities) lead to relatively short steady-state time integration (several weeks), whereas weaker forcings lead to longer steady-state time integration (several months). Initial conditions far or close to the final equilibrium state only affect the initial response of the model and the way the model reaches the asymptotic. The present physical-biological coupled model was run for the summer period, when the water column at the Malina sampling site was highly stratified and, as a consequence, vertical turbulent fluxes were very low. This physical setting explains the relatively long time needed by the model to reach near equilibrium within 
Table 1. Differential equations for the 10-component plankton ecosystem model: nitrate $\left(\mathrm{NO}_{3}\right)$, ammonium $\left(\mathrm{NH}_{4}\right)$, large and small phytoplankton (LP and SP, respectively), large and small zooplankton (LZ and SZ, respectively), bacteria (BACT), detrital particulate and dissolved organic nitrogen (dPON and dDONl, respectively), and photosensitive dissolved organic nitrogen (DONp).
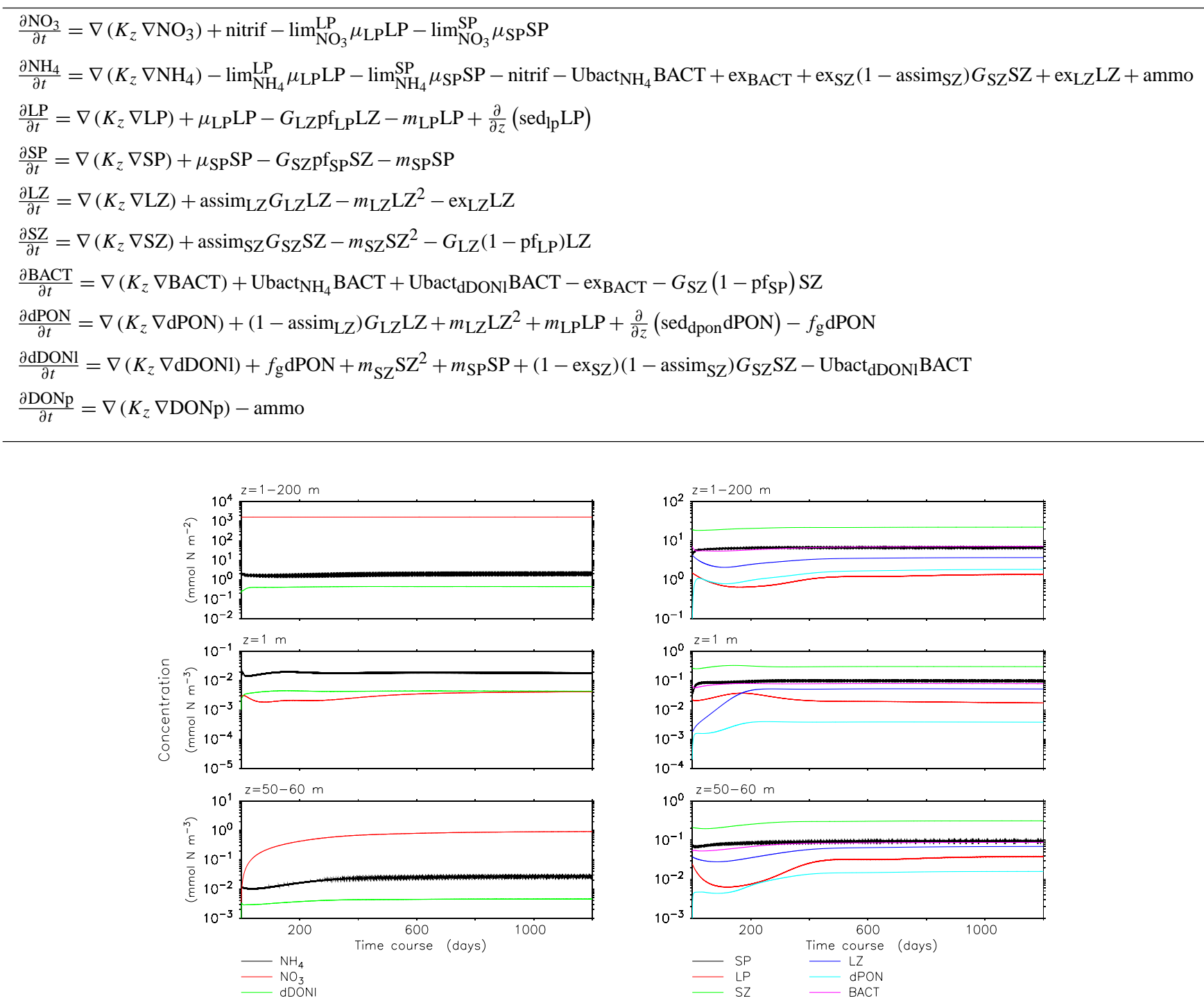

Fig. 4. Time course of the model state variables in the dissolved (left panels) and particulate (right panels) form integrated over the numerical domain (upper panels), at the surface (middle panels) and within the subsurface maximum of primary production (lower panels).

the photic zone. The hypothesis stated is that the ecosystem would never be far from near equilibrium as the timescale required continuously changes in response to the environmental conditions. Rapid environmental changes are generally driven by strong physical forcings promoting a rapid ecosystem response. In contrast, highly stratified conditions as observed at the Malina sampling site generally result from physical processes associated with a timescale of several weeks and to which the ecosystem generally has enough time to adjust to. Finally, the initial conditions of the model were principally defined from observations, which the simulated steady state did not depart too much from. This result sup- ports the stated hypothesis of a near-equilibrium plankton ecosystem under vertically stratified and slowly varying environmental conditions as observed during the Malina cruise. The model outputs at steady state were then compared with time coincident multiparametric measurements (10 a.m. local time for all variables, except for downwelling PAR measured at 11 a.m. local time) (Figs. 5 and 6). The profiles of measured $\mathrm{NO}_{3}, \mathrm{NH}_{4}$, size-fractionated Chl, PON, LZ and bacterial biomass used for the comparison were the same as those used to initiate the model state variables. This approach permits assessment of the model's ability to reproduce the observed concentrations and rates. 

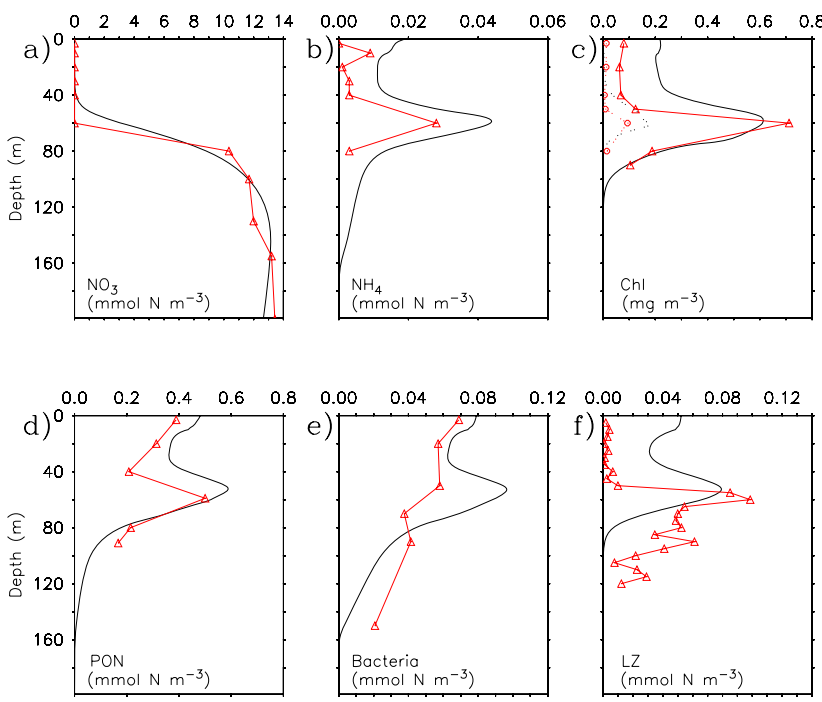

Fig. 5. Model-data comparisons (scalars) for the "standard" run. Model outputs are in black and observations in red: (a) $\mathrm{NO}_{3}$, (b) $\mathrm{NH}_{4}$, (c) Chl for SP and LP (in the model, full and dashed lines, respectively; in observations, triangles and circles, respectively), (d) PON (i.e., sum of LP, SP, SZ, BACT and dPON in the model), (e) biomass of bacteria and (f) LZ.

\subsubsection{Nutrients, light, $\mathrm{Chl}$ and primary production}

Simulated and measured $\mathrm{NO}_{3}$ concentrations $\left(1.4 \times 10^{-3} \mathrm{mmol} \mathrm{N} \mathrm{m}^{-3}\right.$ and $3.1 \times 10^{-3} \mathrm{mmol} \mathrm{N} \mathrm{m}^{-3}$, respectively) were low at the surface but of the same order of magnitude. Below, simulated and measured $\mathrm{NO}_{3}$ concentrations increased with depth to reach $12-14 \mathrm{mmol} \mathrm{N} \mathrm{m}^{-3}$ (Fig. 5a). With respect to $\mathrm{NH}_{4}$, the model reproduced the subsurface peak observed at $\sim 60 \mathrm{~m}$ with a simulated concentration of $\sim 0.042 \mathrm{mmol} \mathrm{N} \mathrm{m}^{-3}$, close to that measured $\left(0.028 \mathrm{mmol} \mathrm{N} \mathrm{m}^{-3}\right)$ (Fig. $5 \mathrm{~b}$ ). At $70 \mathrm{~m}$, below the subsurface peak of $\mathrm{NH}_{4}$, the simulated $\mathrm{NH}_{4}$ nitrification rate $\left(3.3 \times 10^{-3} \mathrm{mmol} \mathrm{N} \mathrm{m}^{-3} \mathrm{~d}^{-1}\right)$ compared with its measured counterpart $\left(6.5 \times 10^{-3} \mathrm{mmol} \mathrm{N} \mathrm{m}^{-3} \mathrm{~d}^{-1}\right)$, the latter being significant but low and hence likely imprecise (detection limit was 6-8 $\times 10^{-4} \mathrm{mmol} \mathrm{N} \mathrm{m}^{-3} \mathrm{~d}^{-1}$ ).

With respect to phytoplankton, production rates and $\mathrm{Chl}$ are highly constrained by variations of the nutrients and light. The shape of the vertical light field was well reproduced by the coupled model as were the simulated PAR values at the surface and within the DCM (Fig. 6a). While the range of measured $\mathrm{C}: \mathrm{N}$ ratios at study station $345(6.744$ at $3 \mathrm{~m}$ and 6.362 at $60 \mathrm{~m}$ ) was analogous to the 6.625 Redfield ratio, the observed POC: Chl ratios showed a $\sim 5$-fold decrease from the surface $\left(\sim 312 \mathrm{~g} \mathrm{~g}^{-1}\right)$ to the DCM $\left(\sim 57 \mathrm{~g} \mathrm{~g}^{-1}\right)$. Assuming phytoplankton carbon can represent $20 \%$ of POC in oligotrophic waters with a high regenerative capability (e.g., Claustre et al., 1999), the observed C: Chl range would reach $\sim 62 \mathrm{~g} \mathrm{~g}^{-1}$ at the surface and $\sim 11 \mathrm{~g} \mathrm{~g}^{-1}$ within the DCM. These values compare with those given by Sherr et
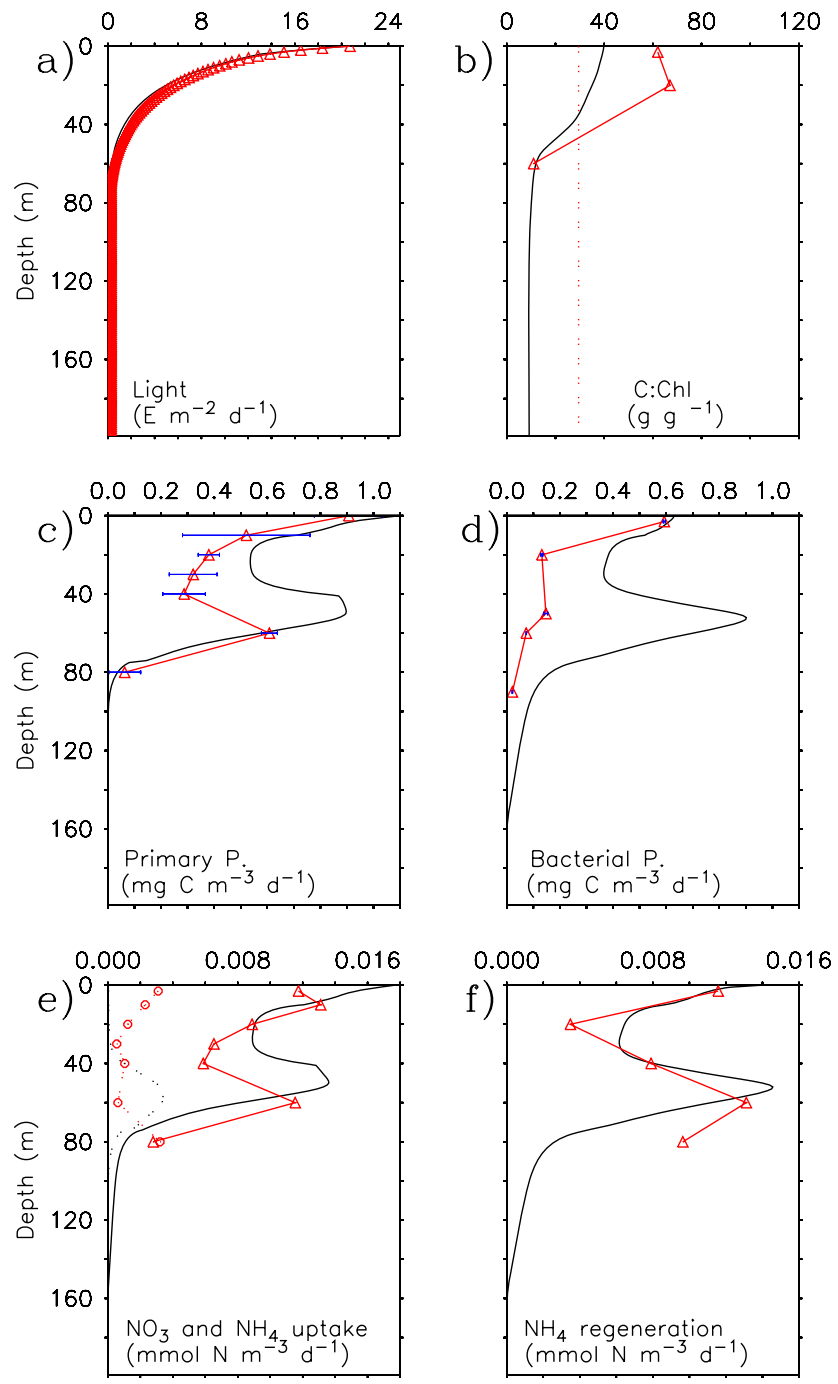

Fig. 6. Model-data comparisons (rates) for the "standard" run. Model outputs are in black and observations in red: (a) downwelling $\mathrm{PAR}$, (b) $\mathrm{C}: \mathrm{Chl}$ ratio (for SP in the model; for the observations derived from Claustre et al. (1999) (see text for details); the vertical dashed line is the mean $\mathrm{C}$ : Chl ratio according to DuRand et al., 2002, and Sherr et al., 2003), (c) primary production, (d) bacterial production, (e) $\mathrm{NH}_{4}$ and $\mathrm{NO}_{3}$ uptake (in the model, full and dashed lines, respectively; in the observations, triangles and circles, respectively) and (f) $\mathrm{NH}_{4}$ regeneration. On panels (c) and (d), the averages \pm standard deviation appear in blue.

al. (2003) and Booth and Horner (1997) for a phytoplankton assemblage dominated by $<5 \mu \mathrm{m}$ sized cells observed in the central oligotrophic AO in summer $\left(13-70 \mathrm{~g} \mathrm{~g}^{-1}, \sim 30 \mathrm{~g} \mathrm{~g}^{-1}\right.$ on average). Furthermore, these studies report abundant picophytoplankton ecotype Micromonas as observed during the Malina cruise (Balzano et al., 2012). DuRand et al. (2002) measured Micromonas sp. cellular carbon and $\mathrm{Chl}$ content and estimated the mean $\mathrm{C}$ : Chl ratio to be $\sim 30 \mathrm{~g} \mathrm{~g}^{-1}$. In that respect, it can be assumed that the simulated $\mathrm{C}: \mathrm{Chl}$ ratios for SP $\left(10-40 \mathrm{~g} \mathrm{~g}^{-1}\right)$ lied within the expected observed range 
(11-63 $\mathrm{g} \mathrm{g}^{-1}$, Fig. 6b). The vertical variations of the measured light saturation parameter $\left(E_{k}\right)\left(1-6 \mathrm{E} \mathrm{m}^{-2} \mathrm{~d}^{-1}\right.$ within the DCM and at the surface, respectively) were reasonably captured by the model $\left(1.5-15 \mathrm{E} \mathrm{m}^{-2} \mathrm{~d}^{-1}\right.$ for $\mathrm{SP}$ within the DCM and at the surface, respectively). The $\mathrm{C}: \mathrm{Chl}$ ratio and $E_{k}$ are key parameters in the computation of $\mathrm{Chl}$ and primary production (PP) in the model.

The model produced a DCM at $\sim 60 \mathrm{~m}$ depth with a total Chl concentration of $\sim 0.8 \mathrm{mg} \mathrm{m}^{-3}$ formed at $78 \%$ by $\mathrm{SP}$, in line with the observations ( $87 \%$; Fig. $5 \mathrm{c})$. At the surface, the higher simulated SP Chl $\left(0.2 \mathrm{mg} \mathrm{m}^{-3}\right)$ than that measured $\left(0.1 \mathrm{mg} \mathrm{m}^{-3}\right)$ likely resulted from a too low simulated C:Chl ratio (Fig. 6a). With respect to PP, the simulated and observed profiles showed similarities in shape and rates (Fig. 6c). In the model, PP was mostly regenerated at the surface ( $f$ ratio of 0.003$)$ and within the subsurface maximum ( $f$ ratio of 0.02 ). The simulated rates were high at the surface $\left(1.1 \mathrm{mg} \mathrm{C} \mathrm{m}^{-3} \mathrm{~d}^{-1}\right)$, decreased within the upper $30 \mathrm{~m}$ and then increased again to reach a subsurface maximum $\left(0.89 \mathrm{mg} \mathrm{C} \mathrm{m}^{-3} \mathrm{~d}^{-1}\right)$ at $\sim 50 \mathrm{~m}$, i.e., $10 \mathrm{~m}$ above the DCM and the subsurface peak of $\mathrm{NH}_{4}$. The $0.26 \mathrm{mg} \mathrm{C} \mathrm{m}^{-3} \mathrm{~d}^{-1}$ difference with the measured subsurface maximum $\left(0.63 \mathrm{mg} \mathrm{C} \mathrm{m}^{-3} \mathrm{~d}^{-1}\right)$ likely resulted from the slight shallowing of the subsurface PP maximum in the model, hence providing SP a higher light availability (see Fig. 6a.).

\subsubsection{Nutrient recycling}

As for PP, the profiles of simulated and observed $\mathrm{NH}_{4}$ uptake and regeneration showed similar shapes and values (Fig. 6e, f). $\mathrm{NH}_{4}$ uptake in both measurements and the model was due to phytoplankton and bacteria. While their respective contribution is difficult to assess in situ, phytoplankton and bacteria in the model respectively consumed $78 \%$ and $22 \%$ of the $\mathrm{NH}_{4}$ pool at the surface, and $62 \%$ and $38 \%$ within the subsurface maximum of PP. Based on the measurements, the subsurface maximum of total PP $\left(0.63 \mathrm{mg} \mathrm{C} \mathrm{m}^{-3} \mathrm{~d}^{-1}\right)$ would represent $0.0075 \mathrm{mmol} \mathrm{N} \mathrm{m}^{-3} \mathrm{~d}^{-1}$ assuming a Redfieldian ratio. Subtracting the measured $\mathrm{NO}_{3}$ uptake $\left(0.0006 \mathrm{mmol} \mathrm{N} \mathrm{m}^{-3} \mathrm{~d}^{-1}\right)$ from the total PP measured $\left(0.0115 \mathrm{mmol} \mathrm{N} \mathrm{m}^{-3} \mathrm{~d}^{-1}\right)$ would approximate the regenerated PP to $0.0073 \mathrm{mmol} \mathrm{N} \mathrm{m}^{-3} \mathrm{~d}^{-1}$. By reducing this value from the measured $\mathrm{NH}_{4}$ uptake, the bacterial $\mathrm{NH}_{4}$ uptake rate in data would be $0.0043 \mathrm{mmol} \mathrm{N} \mathrm{m}^{-3} \mathrm{~d}^{-1}$. Assuming no mixotrophy, phytoplankton and bacteria would respectively be responsible for $63 \%$ and $37 \%$ of the total $\mathrm{NH}_{4}$ uptake measured at the station DCM, which was very similar to what was simulated by the coupled model within the subsurface maximum of PP.

In the model, $\mathrm{NH}_{4}$ regeneration is driven by $\mathrm{SZ}(49.4 \%)$, bacteria $(28.2 \%)$ and photoammonification $(22.4 \%)$ at the surface, and by SZ (65.5\%) and bacteria (34.5\%) within the subsurface maximum. Although not estimated during the cruise, the SZ biomass simulated by the model and averaged over the top $40 \mathrm{~m}\left(19 \mathrm{mg} \mathrm{C} \mathrm{m}^{-3}\right)$ lied within the upper range reported in summer in the central Arctic Ocean $\left(1-18 \mathrm{mg} \mathrm{Cm}^{-3}\right.$ on average between the surface and $40 \mathrm{~m}$; Sherr et al., 2003). The simulated bacterial biomass $\left(0.065-0.08 \mathrm{mg} \mathrm{C} \mathrm{m}^{-3}\right)$ was near the measured values $\left(0.06-0.07 \mathrm{mg} \mathrm{C} \mathrm{m}^{-3}\right)$ within the upper $20 \mathrm{~m}$, but was 1.6 -fold higher at $50 \mathrm{~m}$ (Fig. 5e). Similarly, the simulated bacterial production at the surface matched that estimated from measurements $\left(0.6 \mathrm{mg} \mathrm{C} \mathrm{m}^{-3} \mathrm{~d}^{-1}\right)$, but was 6fold higher at $50 \mathrm{~m}\left(0.9 \mathrm{mg} \mathrm{C} \mathrm{m}^{-3} \mathrm{~d}^{-1}\right)$ (Fig. 6d). At this station, the bacterial growth was found to be strictly $\mathrm{N}-$ limited at the surface, but co-limited in $\mathrm{N}$ and $\mathrm{C}$ within the DCM (Ortega-Retuerta et al., 2012b). Carbon limitation, which was not accounted for in the bacterial growth model due to the large uncertainty in assessing the fraction of the total DOC pool that can be taken up for growth, partly explained the discrepancy. Temperature decreasing with depth at the study site was also shown to constrain bacterial production (Ortega-Retuerta et al., 2012a). Nevertheless, the overestimation by the model of the bacterial biomass $\left(0.04 \mathrm{mmol} \mathrm{N} \mathrm{m}^{-3}\right)$ only had a limited impact on the subsurface plankton dynamics and total PON concentration (i.e., the sum of phytoplankton, SZ, bacteria and $\mathrm{dPON}$ in the model) (Fig. 5d). A model run (not shown) initiated with the interpolated profile of measured bacterial biomass and with the steady-state solutions of the "standard run" for the other 9 state variables showed that the simulated $\mathrm{NH}_{4}$ regeneration $\left(0.011 \mathrm{mmol} \mathrm{N} \mathrm{m}^{-3} \mathrm{~d}^{-1}\right)$ would still fairly approximate the measured value $\left(0.014 \mathrm{mmolN} \mathrm{m}^{-3} \mathrm{~d}^{-1}\right)$.

Because of its grazing activity, LZ shaped the biomass of $\mathrm{SZ}$ and, as a result, controlled its nitrogen remineralization activity. The simulated biomass of LZ showed a maximum at $50 \mathrm{~m}\left(0.08 \mathrm{mmol} \mathrm{N} \mathrm{m}^{-3}\right)$, i.e., $10 \mathrm{~m}$ above the observed maximum $\left(0.1 \mathrm{mmol} \mathrm{N} \mathrm{m}^{-3}\right)$ (Fig. $5 \mathrm{f}$ ). In the upper $40 \mathrm{~m}$, the mean simulated biomass was, however, one order of magnitude higher $\left(0.035 \mathrm{mmol} \mathrm{N} \mathrm{m}^{-3}\right)$ than in those measured $\left(0.0025 \mathrm{mmol} \mathrm{N} \mathrm{m}^{-3}\right)$. As no LZ diurnal migrations were set in the model, the LZ biomass varied only as a function of the biomass of prey, namely SZ at the surface. Note, however, that within the top $40 \mathrm{~m} \mathrm{LZ}$ grazing $\left(0.04 \mathrm{mmol} \mathrm{N} \mathrm{m}^{-2} \mathrm{~d}^{-1}\right)$ was not the primary loss term of the SZ biomass. It was SZ basal mortality $\left(0.075 \mathrm{mmol} \mathrm{N} \mathrm{m}^{-2} \mathrm{~d}^{-1}\right)$, and hence the higher LZ biomass had a limited impact on SZ biomass in surface waters. At $90 \mathrm{~m}$, the simulated flux of fecal pellets (2.0 $\mathrm{mg} \mathrm{C} \mathrm{m}^{-2} \mathrm{~d}^{-1}$, assuming a $\mathrm{C}: \mathrm{N}$ ratio of 8.3) was in fair agreement with that estimated from sediment traps deployed at the same depth $\left(<1.2 \mathrm{mg} \mathrm{C} \mathrm{m}^{-2} \mathrm{~d}^{-1}\right)$ (J. C. Miquel, personal communication, 2013). 


\subsection{Model sensitivity to light-related processes}

\subsubsection{Photosensitive DON photoammonification into $\mathrm{NH}_{4}$}

In surface waters, $\mathrm{NH}_{4}$ can be produced from the photochemical degradation of photosensitive DON mediated by ultraviolet (UV) radiation (i.e., photoammonification; see Bushaw et al., 1996). This photochemical process was set up in the model in a simple fashion using an empirical formulation (Eq. 24 in the Appendix) linking the decrease with depth of a mean photoammonification rate within the upper $10 \mathrm{~m}$ (Xie et al., 2012). This approach based on measurements had been chosen at the expense of a more complex bio-optical spectral model involving accurate daily UV data, which were not available for station 345 .

A simulation without the photoammonification process ("no photoammonification" run) was run in order to assess the contribution of this photochemical process to PP and its role in the plankton ecosystem functioning. During the time window simulated by the model, the $10 \%$ UV irradiance depths at $325-340 \mathrm{~nm}(7.8-10.3 \mathrm{~m})$, where the photoammonification rate was the highest (Xie et al., 2012), were the highest encountered during the whole Malina sampling period (Para et al., 2013). A value of $0.0075 \mathrm{mmol} \mathrm{N} \mathrm{m}^{-2} \mathrm{~d}^{-1}$ of $\mathrm{NH}_{4}$ photoproduced from DONp was simulated by the model within the upper $10 \mathrm{~m}$, which compared well with the mean value estimated from measurements in August in the same area $\left(0.008 \mathrm{mmol} \mathrm{N} \mathrm{m}^{-2} \mathrm{~d}^{-1}\right.$; Xie et al., 2012). In the model, photoammonification contributed directly and indirectly to $22.4 \%$ of the total $\mathrm{NH}_{4}$ produced within the upper $10 \mathrm{~m}$. It was the third highest source of $\mathrm{NH}_{4}$ after SZ and bacterial release ( $49.4 \%$ and $28.2 \%$, respectively).

Within the upper $10 \mathrm{~m}$ of the numerical domain, the photoproduction of $\mathrm{NH}_{4}$ translated into a 1.7-fold increase of the total PON biomass (Figs. 5d and 7d). Part of that PON pool, the biomass of bacteria, SZ and SP respectively increased by $84 \%$ (Figs. 5e and 7e), $76 \%$ and $41 \%$. Photoammonification stimulated the SP and bacterial growth, as well as the subsequent $\mathrm{SZ}$ grazing pressure, leading to a 3.1-fold and 3.3-fold increase of the total $\mathrm{NH}_{4}$ production and total $\mathrm{NH}_{4}$ uptake within the top $10 \mathrm{~m}$ (Figs. 6e, $\mathrm{f}$ and $8 \mathrm{e}, \mathrm{f})$. Assuming all the photochemically produced $\mathrm{NH}_{4}$ in the model would be taken up by phytoplankton, it would meet $7 \%$ of its nitrogen demand. This contribution, in clear offshore waters not influenced by the Mackenzie plume, is lower than previous estimates from the Orincco River plume (50\%; Morell and Corredor, 2001) that drains high loads of terrigenous organic matter. In terms of production, photoammonification promoted within the upper $10 \mathrm{~m}$ a 3.4-fold and 3-fold increase of the autotrophic (Fig. $6 \mathrm{c}$ and $8 \mathrm{c}$ ) and bacterial production (Figs. $6 \mathrm{~d}$ and $8 \mathrm{~d}$ ), respectively, in accordance with the 2.9-fold increase reported in the bioassay study of Vähätalo et al. (2011). For the whole water column, it represented a $22.8 \%$ and $19 \%$ increase of the simulated
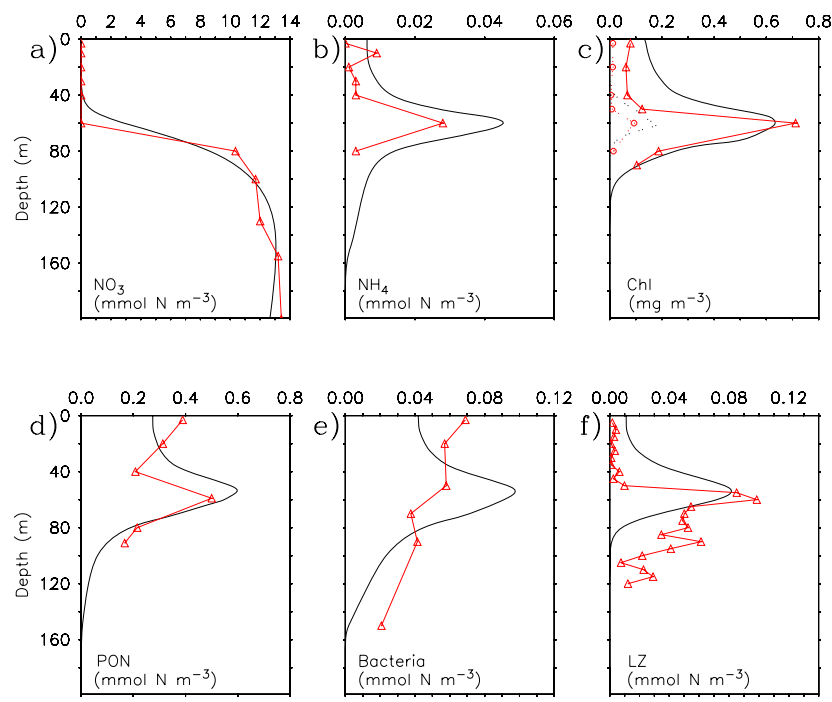

Fig. 7. Model-data comparisons (scalars) for the "no photoammonification" run. Model outputs are in black and observations in red: (a) $\mathrm{NO}_{3}$, (b) $\mathrm{NH}_{4}$, (c) Chl for SP and LP (in the model, full and dashed lines, respectively; in observations, triangles and circles, respectively), (d) PON (i.e., sum of LP, SP, SZ, BACT and dPON in the model), (e) biomass of bacteria and (f) LZ.

PP (39.4 $\mathrm{mg} \mathrm{C} \mathrm{m}^{-2} \mathrm{~d}^{-1}$ to $48.4 \mathrm{mg} \mathrm{C} \mathrm{m}^{-2} \mathrm{~d}^{-1}$ ) and bacterial production ( $38.1 \mathrm{mg} \mathrm{C} \mathrm{m}^{-2} \mathrm{~d}^{-1}$ to $45.4 \mathrm{mg} \mathrm{C} \mathrm{m}^{-2} \mathrm{~d}^{-1}$ ), respectively. The simulated photoammonification rate $\left(0.0075 \mathrm{mmol} \mathrm{N} \mathrm{m}^{-2} \mathrm{~d}^{-1}, 0-10 \mathrm{~m}\right)$ represented $8.3 \%$ of the bacterial production $\left(0.09 \mathrm{mmol} \mathrm{N} \mathrm{m}^{-2} \mathrm{~d}^{-1}, 0-10 \mathrm{~m}\right)$, a contribution close to the upper range given by Vähätalo et al. $(2011 ; 2-5 \%)$. In the model, the photoammonification process is an important driver of the regenerative capability of the system supported by the microbial food web.

\subsubsection{C : Chl ratios}

In the model, the competition for resources between SP and LP was driven primarily by differences in nutrient uptake, light use and $\mathrm{C}: \mathrm{Chl}$ ratios. Simulated $\mathrm{C}: \mathrm{Chl}$ ratios varied according to PAR and nitrogen limitation (see Eqs. 10 and 11 in the Appendix) and constrained the light-based growth rate, which was limiting in the vicinity of DCM. LP was characterized by simulated $\mathrm{C}$ : $\mathrm{Chl}$ ratios between 17 and $73 \mathrm{~g} \mathrm{~g}^{-1}$ while SP showed lower values in the $10-40 \mathrm{~g} \mathrm{~g}^{-1}$ range.

Generally, biogeochemical models applied to the AO typically distinguish diatom phytoplankton from non-diatom phytoplankton. The $\mathrm{C}: \mathrm{Chl}$ ratio used for diatoms generally lies between 33 and $50 \mathrm{~g} \mathrm{~g}^{-1}$ (Slagstad et al., 2011; Walsh et al., 2011; Zhang et al., 2011; Le Fouest et al., 2011; Popova et al., 2010), within the range simulated by the model $\left(17-73 \mathrm{gg}^{-1}\right)$. However, the $\mathrm{C}: \mathrm{Chl}$ ratio used for non-diatom phytoplankton varies amongst the different models. Generally invariant in space and time, it can be the same (e.g., Zhang et al., 2010; Le Fouest et al., 2011) or 
more than twice the value used for diatoms $\left(83-100 \mathrm{~g} \mathrm{~g}^{-1}\right.$, e.g., Slagstad et al., 2011; Walsh et al., 2011). These values for non-diatom phytoplankton are much higher than those simulated for SP in the model (10-40 $\mathrm{g} \mathrm{g}^{-1}$, Fig. 6b).

In order to infer the model sensitivity to the $\mathrm{C}: \mathrm{Chl}$ ratios, a simulation accounting for the photoammonification process but now using time- and depth-invariant $\mathrm{C}$ : $\mathrm{Chl}$ ratios respectively of 50 and $100 \mathrm{~g} \mathrm{~g}^{-1}$ for LP and SP was run ("constant $\mathrm{C}: \mathrm{Chl}$ " run) and compared to observations (Figs. 9 and 10). In the top $40 \mathrm{~m}$, a higher $\mathrm{C}: \mathrm{Chl}$ ratio for SP translated into simulated $\mathrm{Chl}$ concentrations the closest to the measurements $\left(<0.1 \mathrm{mg} \mathrm{Chl} \mathrm{m}^{-3}\right.$; Figs. $5 \mathrm{c}$ and $\left.9 \mathrm{c}\right)$, suggesting that in the "standard" run the simulated $\mathrm{C}: \mathrm{Chl}$ ratios were likely underestimated. Similarly, the simulated total PON, bacterial and LZ concentrations decreased and showed the best agreement with the observations (Figs. 9d-f). With respect to the simulated rates, the $0-40 \mathrm{~m}$ integrated $\mathrm{NH}_{4}$ uptake and primary and bacterial production decreased in the "constant $\mathrm{C}$ : Chl” run $\left(0.36 \mathrm{mmol} \mathrm{N} \mathrm{m}^{-2} \mathrm{~d}^{-1}, \quad 22.2 \mathrm{mg} \mathrm{C} \mathrm{m}^{-2} \mathrm{~d}^{-1}\right.$, and $13.7 \mathrm{mg} \mathrm{C} \mathrm{m}^{-2} \mathrm{~d}^{-1}$, respectively) relative to the "standard" run $\left(0.43 \mathrm{mmol} \mathrm{N} \mathrm{m}^{-2} \mathrm{~d}^{-1}, 26 \mathrm{mg} \mathrm{C} \mathrm{m}^{-2} \mathrm{~d}^{-1}\right.$, and $17.6 \mathrm{mg} \mathrm{C} \mathrm{m}^{-2} \mathrm{~d}^{-1}$, respectively) and better approximated the measured rates $\left(0.37 \mathrm{mmol} \mathrm{N} \mathrm{m}^{-2} \mathrm{~d}^{-1}\right.$, $18.2 \mathrm{mg} \mathrm{C} \mathrm{m}^{-2} \mathrm{~d}^{-1}$, and $10.6 \mathrm{mg} \mathrm{C} \mathrm{m}^{-2} \mathrm{~d}^{-1}$, respectively). However, the use of constant $\mathrm{C}: \mathrm{Chl}$ ratios prevented below the development of a DCM formed principally by SP, as observed (Fig. 9c). Instead, the LP DCM moved $10 \mathrm{~m}$ upward in response to changes in the nutrient dynamics. In terms of nitrogenous biomass, LP contributed more to total PON (33\%) within the subsurface maximum as compared to the "standard" run $(7 \%)$. The simulated PP $\left(0.49 \mathrm{mg} \mathrm{C} \mathrm{m}^{-3} \mathrm{~d}^{-1}\right)$ was lower by $55 \%$ than in the "standard" run (0.89 $\left.\mathrm{mg} \mathrm{C} \mathrm{m}^{-3} \mathrm{~d}^{-1}\right)$ (Figs. 6c and 10c), but with a larger contribution of new production ( $f$ ratio of 0.43 versus 0.27 in the "standard" run). By contrast, the activity of the microbial food web dropped in the vicinity of the DCM, as illustrated by the 3.7-fold decrease of the $\mathrm{NH}_{4}$ regeneration (Fig. 10f) ensured by SZ and bacteria. SZ represented $31 \%$ of the total PON pool in the "constant $\mathrm{C}: \mathrm{Chl}$ " run, which was about half the contribution in the "standard" run (57\%). Similarly, the bacterial biomass and production decreased by $54 \%$ and $75 \%$ (Figs. 9e and 10d), respectively. These changes in the plankton ecosystem structure and functioning showed that simulated $\mathrm{C}: \mathrm{Chl}$ ratios, which constrained the light-based phytoplankton growth rate in the model, were important drivers of the large versus small phytoplankton competition within the system.

\subsection{Concluding remarks}

The low productive waters encountered at the outer-shelf station 345 during the August 2009 Malina cruise in the Beaufort Sea $\left([\mathrm{Chl}]=0.7 \mathrm{mg} \mathrm{m}^{-3}\right.$ and $\mathrm{PP}=0.6 \mathrm{mg} \mathrm{C} \mathrm{m}^{-3} \mathrm{~d}^{-1}$ within the DCM) strikingly contrasted with the conditions reported in summer in other shelf seas as the Chukchi, Bar-
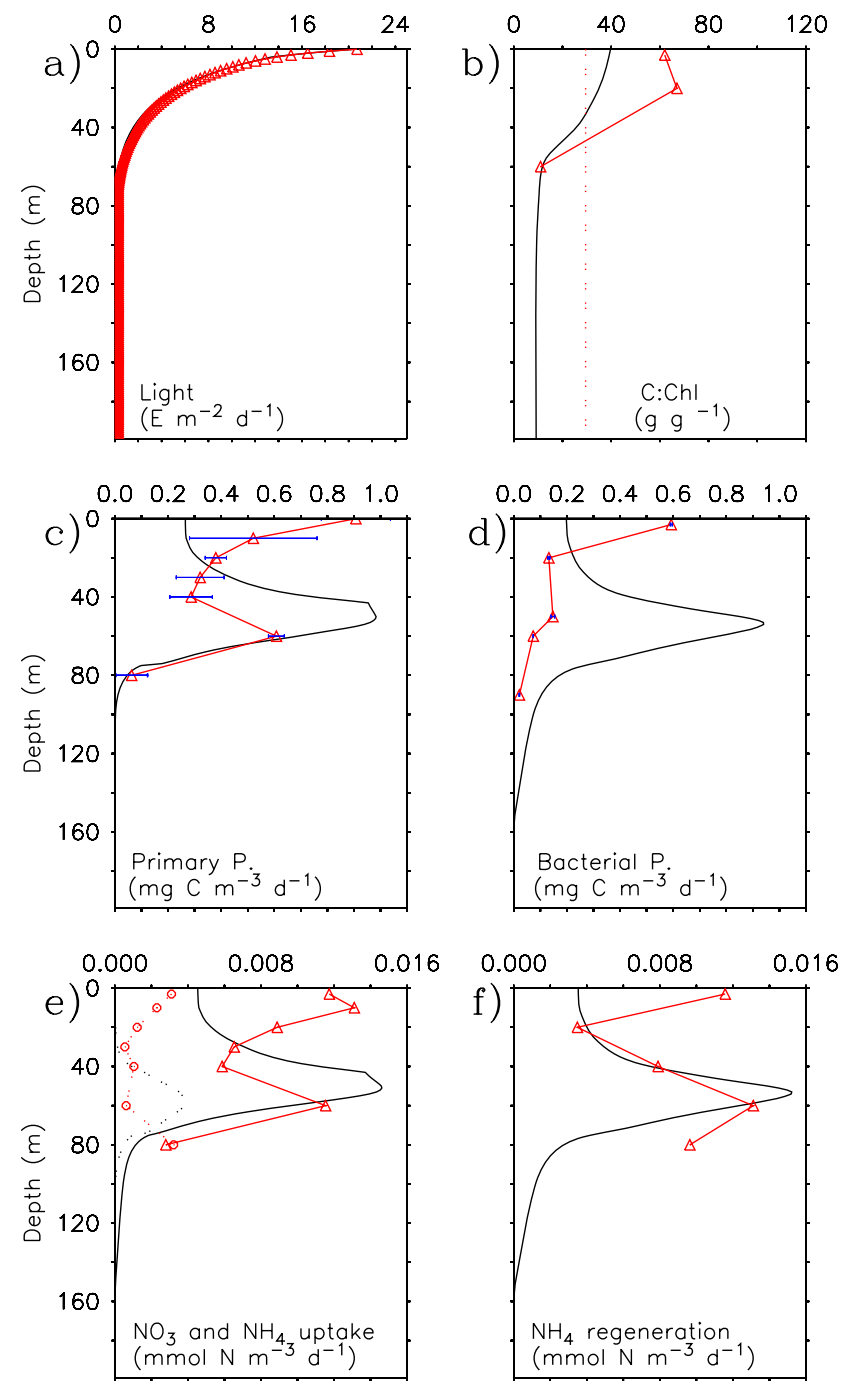

Fig. 8. Model-data comparisons (rates) for the "no photoammonification" run. Model outputs are in black and observations in red: (a) downwelling PAR, (b) $\mathrm{C}: \mathrm{Chl}$ ratio (for SP in the model; for the observations derived from Claustre et al.,1999 (see text for details); the vertical dashed line is the mean $\mathrm{C}$ : Chl ratio according to DuRand et al., 2002, and Sherr et al., 2003), (c) primary production, (d) bacterial production, (e) $\mathrm{NH}_{4}$ and $\mathrm{NO}_{3}$ uptake (in the model, full and dashed lines, respectively; in the observations, triangles and circles, respectively) and (f) $\mathrm{NH}_{4}$ regeneration. In (c) and (d), the averages \pm standard deviation appear in blue.

ents and western Beaufort seas $\left([\mathrm{Chl}]=2-11 \mathrm{mg} \mathrm{m}^{-3}\right.$ and $\mathrm{PP}=10-300 \mathrm{mg} \mathrm{C} \mathrm{m}^{-3} \mathrm{~d}^{-1}$; Zhang et al., 2011; Matrai et al., 2007; Reigstad et al., 2002). In this context, a 1-D physicalbiological coupled model was developed to gain a better understanding of the plankton ecosystem functioning in these stratified, clear and very oligotrophic waters. The coupled model was forced by a stationary field of vertical turbulent diffusion and by a diurnal cycle of surface PAR based on measurements made at station 345 (Fig. 1). Simulations at steady state were produced and the outputs compared to an 

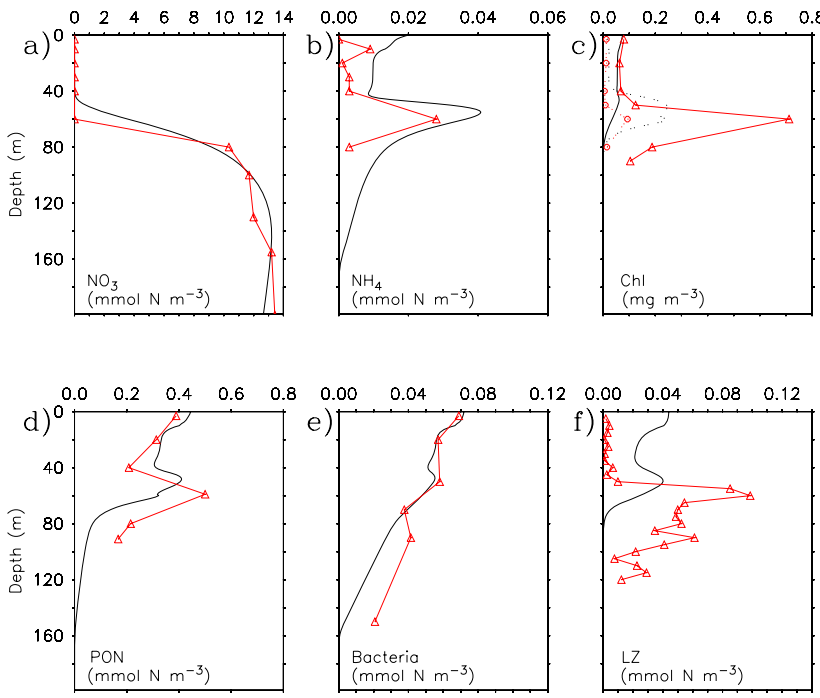

Fig. 9. Model-data comparisons (scalars) for the "constant C : Chl" run. Model outputs are in black and observations in red: (a) $\mathrm{NO}_{3}$, (b) $\mathrm{NH}_{4}$, (c) Chl for SP and LP (in the model, full and dashed lines, respectively; in the observations, triangles and circles, respectively), (d) PON (i.e., sum of LP, SP, SZ, BACT and dPON in the model), (e) biomass of bacteria and (f) LZ.

extensive dataset of space- and time-coincident and multiparametric data sampled at the same station.

The 10-compartment ecosystem model approximated the observed nitrogen fluxes and biomass levels. It suggested that $\mathrm{NH}_{4}$ photoproduced from DONp within the top $10 \mathrm{~m}$ was a necessary nitrogen source to achieve the observed levels of autotrophic and heterotrophic biomass and production. The photochemical process fueled SP-regenerated PP directly through the $\mathrm{NH}_{4}$ uptake by $\mathrm{SP}$ and indirectly by stimulating the heterotrophic protist activity. Increased SP growth stimulated grazing and the subsequent release of $\mathrm{NH}_{4}$ and dDONl by SZ. $\mathrm{NH}_{4}$ was used up by both SP and bacteria, while the latter also beneficiated from $\mathrm{dDONl}$ for growth. Increased bacterial growth led, in turn, to an increased bacterial release of $\mathrm{NH}_{4}$. Photoammonification directly and indirectly (by stimulating the microbial food web activity) contributed to $70 \%$ and $18.5 \%$ of the $0-10 \mathrm{~m}$ and whole water column, respectively, simulated primary production (respectively $66 \%$ and $16 \%$ for the bacterial production). The model also suggested that $\mathrm{C}$ : $\mathrm{Chl}$ ratios $\left(83-100 \mathrm{~g} \mathrm{~g}^{-1}\right)$ typically used for the non-diatom phytoplankton compartment in plankton ecosystem models applied to the $\mathrm{AO}$ were not suitable to reproduce the plankton ecosystem structure of the oligotrophic Beaufort Sea. Applying a $\mathrm{C}: \mathrm{Chl}$ ratio of $100 \mathrm{~g} \mathrm{~g}^{-1}$ for SP in the model led to a DCM dominated by large phytoplankton, ensuring mostly new PP, whereas observations reported an autotrophic community dominated by small phytoplankton growing essentially on regenerated nitrogen. While such a $\mathrm{C}$ : Chl ratio for SP was found suitable for the surface waters, lower values were however required in
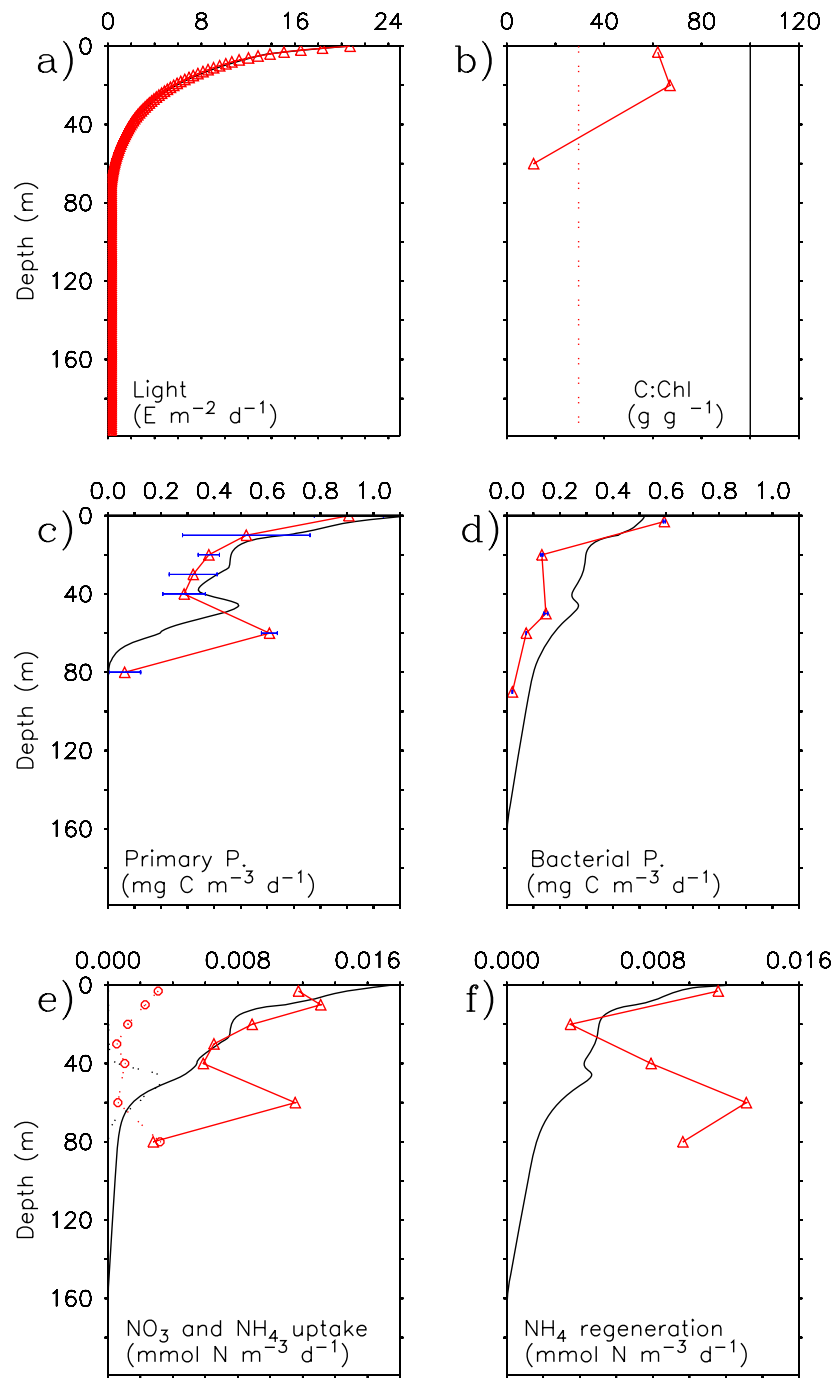

Fig. 10. Model-data comparisons (rates) for the "constant $\mathrm{C}$ : Chl" run. Model outputs are in black and observations in red: (a) downwelling PAR, (b) $\mathrm{C}: \mathrm{Chl}$ ratio (for $\mathrm{SP}$ in the model; for the observations derived from Claustre et al., 1999 (see text for details); the vertical dashed line is the mean C:Chl ratio according to DuRand et al., 2002, and Sherr et al., 2003), (c) primary production, (d) bacterial production, (e) $\mathrm{NH}_{4}$ and $\mathrm{NO}_{3}$ uptake (in the model, full and dashed lines, respectively; in the observations, triangles and circles, respectively) and (f) $\mathrm{NH}_{4}$ regeneration. In (c) and (d), the averages \pm standard deviation appear in blue.

the vicinity of the DCM to simulate the observed herbivorous versus microbial food web competition and realistic nitrogen fluxes, hence highlighting the relevancy of modeling variable $\mathrm{C}: \mathrm{Chl}$ ratios in response to abiotic and biotic conditions.

The accelerated sea ice shrinking and thinning might promote in the AO deep changes in autotrophic and heterotrophic biomass levels, production rates and carbon export (Wassmann and Reigstad, 2011; Li et al., 2009, Arrigo et al., 2008). Enhanced stratification and nutrient limitation already suggest the increasing role of the microbial 
food web in the plankton ecosystem in some parts of the AO (Li et al., 2009; Tremblay et al., 2009). In this context and in view of the current modeling effort in assessing the oceanic (e.g., Le Fouest et al., 2010; Popova et al., 2010) and continental (e.g., Tank et al., 2012) drivers for AO primary production, more attention should be paid in the future to the mechanistic processes involved in food webs and functional group competition, nutrient recycling and primary production in poorly productive Arctic waters as they are expected to expand rapidly (Wassmann and Reigstad, 2011). In particular, the still debated real contribution of the summer DCM in the annual primary production budget should be clarified (e.g., Ardyna et al., 2013; Popova et al., 2010). Such a better knowledge is required for robust model projections of $\mathrm{AO}$ primary production and carbon fluxes in response to the accelerated Arctic sea ice decline.

\section{Appendix A}

The set of differential equations that include the mechanistic formulations cited below is given in Table 1. The biological parameters related to the mathematical equations are detailed in Table A1.

\section{A1 Phytoplankton}

The growth rate $\left(\mu^{\mathrm{LP}, \mathrm{SP}}, \mathrm{d}^{-1}\right)$ of large and small phytoplankton (LP and SP, respectively) depends on both light and nitrogen availability. It is computed according to the Liebig's law of the minimum between the nutrient-based and light-based growth rates $\left(\mu_{N}^{\mathrm{LP}, \mathrm{SP}}\right.$ and $\mu_{\text {light }}^{\mathrm{LP}, \mathrm{SP}}$, respectively).

$\mu^{\mathrm{LP}, \mathrm{SP}}=\left(\mu_{N}^{\mathrm{LP}, \mathrm{SP}}, \mu_{\text {light }}^{\mathrm{LP}, \mathrm{SP}}\right)$

The nutrient-based growth rate is computed as follows:

$\mu_{N}^{\mathrm{LP}, \mathrm{SP}}=\mu_{\max }^{\mathrm{LP}, \mathrm{SP}} \lim _{N}^{\mathrm{LP}, \mathrm{SP}}$,

where $\mu_{\text {max }}^{\mathrm{LP}, \mathrm{SP}}$ is the maximum growth rate and $\lim _{N}^{\mathrm{LP}, \mathrm{SP}}$ the total nutrient limitation term (dimensionless) computed according to the substitutable model of O'Neill et al. (1989):

$\lim _{N}^{\mathrm{LP}, \mathrm{SP}}=\frac{\mathrm{NO}_{3} K_{\mathrm{NH}_{4}}^{\mathrm{LP}, \mathrm{SP}}+\mathrm{NH}_{4} K_{\mathrm{NO}}^{\mathrm{LP}, \mathrm{SP}}}{\mathrm{NO}_{3} K_{\mathrm{NH}_{4}}^{\mathrm{LP}, \mathrm{SP}}+\mathrm{NH}_{4} K_{\mathrm{NO}_{3}}^{\mathrm{LP}, \mathrm{SP}}+K_{\mathrm{NH}_{4}}^{\mathrm{LP}, \mathrm{SP}} K_{\mathrm{NO}_{3}}^{\mathrm{LP}, \mathrm{SP}}}$,

$\lim _{\mathrm{NO}_{3}}^{\mathrm{LP}, \mathrm{SP}}=\frac{\mathrm{NO}_{3} K_{\mathrm{NH}}^{\mathrm{LP}, \mathrm{SP}}}{\mathrm{NO}_{3} K_{\mathrm{NH}_{4}}^{\mathrm{LP}, \mathrm{SP}}+\mathrm{NH}_{4} K_{\mathrm{NO}}^{\mathrm{LP}, \mathrm{SP}}}$, and

$\lim _{\mathrm{NH}_{4}}^{\mathrm{LP}, \mathrm{SP}}=\frac{\mathrm{NH}_{4} K_{\mathrm{NO}}}{\mathrm{LP}, \mathrm{SP}}$ where $\lim _{\mathrm{NO}_{3}}^{\mathrm{LP}, \mathrm{SP}}$ and $\lim _{\mathrm{NH}}^{\mathrm{LP}, \mathrm{SP}}$ are the nitrate $\left(\mathrm{NO}_{3}\right)$ and ammonium $\left(\mathrm{NH}_{4}\right)$ uptake fractions, respectively. $K_{\mathrm{NH}_{4}}^{\mathrm{LP}, \mathrm{SP}}$ and $K_{\mathrm{NO}}^{\mathrm{LP}, \mathrm{SP}}$ are the half-saturation for $\mathrm{NH}_{4}$ and $\mathrm{NO}_{3}$ uptake, respectively. $\mathrm{NH}_{4}$ is set to be the preferred inorganic nitrogen source (Dorch, 1990) with a higher affinity for SP (Tremblay et al., 2000). This is expressed in the model by half-saturation constants for $\mathrm{NH}_{4}$ uptake $\left(K_{\mathrm{NH}}^{\mathrm{LP}, \mathrm{SP}}\right)$ significantly lower than for $\mathrm{NO}_{3}$ that, when used with the substitutable model, allow for an inhibitory effect of $\mathrm{NH}_{4}$ on $\mathrm{NO}_{3}$ uptake as often observed (Dorch, 1990). The equation used to compute the light-based growth rate is

$\mu_{\text {light }}^{\mathrm{LP}, \mathrm{SP}}=\mu_{\max }^{\mathrm{LP}, \mathrm{SP}} \lim _{\text {light }}^{\mathrm{LP}, \mathrm{SP}}$,

where $\lim _{\text {light }}^{\mathrm{LP}, \mathrm{SP}}$ is the light limitation term (dimensionless) expressed as

$\lim _{\text {light }}^{\mathrm{LP}, \mathrm{SP}}=1-e^{-\frac{E_{z}}{E_{k}^{\mathrm{LP}, \mathrm{SP}}}}$,

where $E_{k}^{\mathrm{LP}, \mathrm{SP}}$ is the light saturation parameter $\left(\mathrm{E} \mathrm{m}^{-2} \mathrm{~d}^{-1}\right)$ computed as follows:

$E_{k}^{\mathrm{LP}, \mathrm{SP}}=\left(\frac{\mathrm{C}}{\mathrm{Chl}}\right)^{\mathrm{LP}, \mathrm{SP}} \frac{\mu_{\max }^{\mathrm{LP}, \mathrm{SP}}}{\alpha_{\mathrm{LP}, \mathrm{SP}}}$,

where $\mathrm{C}: \mathrm{Chl}$ is the carbon to $\mathrm{Chl}$ ratio $\left(\mathrm{g} \mathrm{g}^{-1}\right)$ and $\alpha_{\mathrm{LP}, \mathrm{SP}}$ the initial slope $\left(\mathrm{mgC}(\mathrm{mg} \mathrm{Chl})^{-1}\left(\mathrm{E} \mathrm{m}^{-2} \mathrm{~d}^{-1}\right)^{-1}\right)$ of the photosynthesis-irradiance curve. Photoacclimation translates the adaptive response through varying $\mathrm{Chl}: \mathrm{C}$ ratios in response to light and nutrient availability (e.g., Cloern et al., 1995; Geider et al., 1997; MacIntyre et al., 2002). Values of $\alpha$ were measured during the Malina cruise at $0-3 \mathrm{~m}$ and $65 \mathrm{~m}$ depth. On average for the study station 345, values of $\alpha$ showed a decrease from the surface $\left(2.22 \mathrm{mgC}(\mathrm{mgChl})^{-1}\left(\mathrm{E} \mathrm{m}^{-2} \mathrm{~d}^{-1}\right)^{-1}\right)$ to the DCM (6.94 mg C $\left.(\mathrm{mg} \mathrm{Chl})^{-1}\left(\mathrm{E} \mathrm{m}^{-2} \mathrm{~d}^{-1}\right)^{-1}\right)$. For SP, which dominates the $\mathrm{Chl}$ biomass, a linear function relating measured $\alpha$ values to depth is set from the surface to $65 \mathrm{~m}$ to account for this decrease:

$\alpha_{\mathrm{SP}}=0.0826315 z+1.9721055$.

A constant value of $5.55 \mathrm{mg} \mathrm{C}(\mathrm{mg} \mathrm{Chl})^{-1}\left(\mathrm{E} \mathrm{m}^{-2} \mathrm{~d}^{-1}\right)^{-1}$ is set below $65 \mathrm{~m}$ based on reported measurements. For LP, a constant value of $2 \mathrm{mgC}(\mathrm{mg} \mathrm{Chl})^{-1}\left(\mathrm{E} \mathrm{m}^{-2} \mathrm{~d}^{-1}\right)^{-1}$ is set to $\alpha_{\mathrm{LP}}$ for the whole vertical numerical domain.

Varying $\mathrm{Chl}$ : $\mathrm{C}$ ratios are computed using a modified version of the empirical relationship of Cloern et al. (1995), successfully applied to Hudson Bay in the Arctic (Sibert et al., 2011). The ratios can vary up to 4 - to 6 -fold based on the general photoacclimation rule given by MacIntyre et al. (2002) and on Arctic nano- and picophytoplankton data (DuRand et al., 2002; Sherr et al., 2003) as follows:

$\left(\frac{\mathrm{Chl}}{\mathrm{C}}\right)^{\mathrm{LP}}=\left(\frac{\mathrm{Chl}}{\mathrm{C}}\right)_{\min }^{\mathrm{LP}}\left(1+4 e^{-0.5 \frac{E_{Z}}{K_{E}^{\mathrm{LP}}}} \lim _{N}^{\mathrm{LP}}\right)$ and 
Table A1. Model parameters.

\begin{tabular}{|c|c|c|c|}
\hline Symbol & Description & Value & Units \\
\hline $\mathrm{kw}$ & Light attenuation coefficient due to water & 0.04 & $\mathrm{~m}^{-1}$ \\
\hline knonchl & Light attenuation coefficient due to non-chlorophyllous matter & 0.05 & $\mathrm{~m}^{-1}$ \\
\hline$K_{\mathrm{NO}_{3}}^{\mathrm{LP}}$ & Half-saturation constant for $\mathrm{NO}_{3}$ use by LP & 1 & $\mathrm{mmol} \mathrm{N} \mathrm{m}^{-3}$ \\
\hline$K_{\mathrm{NO}_{3}}^{\mathrm{SP}}$ & Half-saturation constant for $\mathrm{NO}_{3}$ use by SP & 10 & $\mathrm{mmol} \mathrm{N} \mathrm{m}^{-3}$ \\
\hline$K_{\mathrm{NH}_{4}}^{\mathrm{LP}^{3}}$ & Half-saturation constant for $\mathrm{NH}_{4}$ use by LP & 0.5 & $\mathrm{mmol} \mathrm{N} \mathrm{m}^{-3}$ \\
\hline$K_{\mathrm{NH}_{4}}^{\mathrm{SP}_{4}}$ & Half-saturation constant for $\mathrm{NH}_{4}$ use by SP & 0.1 & $\mathrm{mmol} \mathrm{N} \mathrm{m}{ }^{-3}$ \\
\hline$K_{E}^{\mathrm{LP}}$ & Photoacclimation parameter & 8 & $\mathrm{Em}^{-2} \mathrm{~d}^{-1}$ \\
\hline$K_{E}^{\mathrm{SP}}$ & Photoacclimation parameter & 4 & $E m^{-2} d^{-1}$ \\
\hline$\left(\frac{\mathrm{Chl}}{\mathrm{C}}\right)_{\min }^{\mathrm{LP}}$ & Minimum Chl to $\mathrm{C}$ ratio for $\mathrm{LP}$ & 0.0125 & $\mathrm{gg}^{-1}$ \\
\hline$\left(\frac{\mathrm{Chl}}{\mathrm{C}}\right)_{\min }^{\mathrm{SP}}$ & Minimum $\mathrm{Chl}$ to $\mathrm{C}$ ratio for $\mathrm{SP}$ & 0.02 & $\mathrm{~g} \mathrm{~g}^{-1}$ \\
\hline$\mu_{\max }^{\mathrm{LP}}$ & Maximum growth rate for LP & 1.2 & $d^{-1}$ \\
\hline$\mu_{\max }^{\mathrm{SP}}$ & Maximum growth rate for SP & 0.9 & $d^{-1}$ \\
\hline sed_lp & LP sinking rate & 0.075 & $\mathrm{~m}^{-1}$ \\
\hline$m_{\mathrm{LP}}$ & LP basal mortality & 0.01 & $d^{-1}$ \\
\hline$m_{\mathrm{SP}}$ & SP basal mortality & 0.01 & $\mathrm{~d}^{-1}$ \\
\hline$G_{\mathrm{LZ}}^{\max }$ & Maximum grazing rate for $\mathrm{LZ}$ & 0.3 & $\mathrm{~d}^{-1}$ \\
\hline$\lambda^{\mathrm{L} Z}$ & Ivlev constant for $\mathrm{LZ}$ & 0.35 & $\left(\operatorname{mmol~N~m}{ }^{-3}\right)^{-1}$ \\
\hline$G_{\mathrm{SZ}}^{\max }$ & Maximum grazing rate for SZ & 1 & $\mathrm{~d}^{-1}$ \\
\hline$K_{G}$ & Half-saturation constant for SZ grazing & 0.8 & $\mathrm{mmol} \mathrm{N} \mathrm{m}{ }^{-3}$ \\
\hline $\operatorname{assim}_{\mathrm{LZ}}$ & $\mathrm{LZ}$ assimilation & 0.7 & $\%$ \\
\hline $\operatorname{assim}_{\mathrm{SZ}}$ & SZ assimilation & 0.3 & $\%$ \\
\hline $\mathrm{ex}_{\mathrm{SZ}}$ & dDONl egestion by SZ & 0.3 & $\%$ \\
\hline$e_{L Z}$ & $\mathrm{NH}_{4}$ excretion by $\mathrm{LZ}$ & 0.01 & $\mathrm{~d}^{-1}$ \\
\hline$m_{\mathrm{SZ}}$ & SZ mortality & 0.025 & $\left(\mathrm{mmol} \mathrm{Nm} \mathrm{m}^{-3}\right)^{-1}$ \\
\hline$m_{\mathrm{LZ}}$ & LZ mortality & 0.2 & $\left.(\mathrm{mmol} \mathrm{N} \mathrm{m})^{-3}\right)^{-1}$ \\
\hline Ubact $_{\max }$ & BACT maximum growth rate & 2 & $\mathrm{~d}^{-1}$ \\
\hline$K_{\mathrm{NH}_{4}}^{\mathrm{BACT}}$ & Half-saturation constant for $\mathrm{NH}_{4}$ use by BACT & 0.1 & $\mathrm{mmol} \mathrm{N} \mathrm{m}^{-3}$ \\
\hline$K_{\mathrm{dDON} 1}^{\mathrm{BACT}}$ & Half-saturation constant for dDONl use by BACT & 0.1 & $\mathrm{mmol} \mathrm{N} \mathrm{m}^{-3}$ \\
\hline ex $\mathrm{BACT}$ & $\mathrm{NH}_{4}$ release by bacteria & 0.05 & $\%$ \\
\hline sed_dpon & dPON sinking rate & 100 & $\mathrm{md}^{-1}\left(\mathrm{mmol} \mathrm{N} \mathrm{m}^{-3}\right)^{-1}$ \\
\hline$f_{\mathrm{g}}$ & dPON fragmentation & 0.05 & $d^{-1}$ \\
\hline nitrif $_{\max }$ & Maximum $\mathrm{NH}_{4}$ nitrification rate & 0.3 & $\mathrm{~d}^{-1}$ \\
\hline$K_{\text {nitrif }}^{N}$ & Half-saturation constant for $\mathrm{NH}_{4}$ nitrification & 0.007 & $\mathrm{mmol} \mathrm{N} \mathrm{m}^{-3}$ \\
\hline
\end{tabular}

$\left(\frac{\mathrm{Chl}}{\mathrm{C}}\right)^{\mathrm{SP}}=\left(\frac{\mathrm{Chl}}{\mathrm{C}}\right)_{\min }^{\mathrm{SP}}\left(1+6 e^{-0.5 \frac{E_{z}}{K_{E}^{\mathrm{SP}}}} \lim _{N}^{\mathrm{SP}}\right)$

where $K_{E}^{\mathrm{LP}, \mathrm{SP}}$ is the half-saturation parameter driving the curvature of the $\mathrm{Chl}: \mathrm{C}$ versus light relationship. $E_{z}$ $\left(\mathrm{E} \mathrm{m}^{-2} \mathrm{~d}^{-1}\right)$ is the downwelling PAR propagating according to the Beer-Lambert's law:

$E_{z}=\operatorname{PAR} 0 \int e^{-[(\mathrm{kchl}+\mathrm{kw}+\mathrm{knonchl}) z] \mathrm{d} z}$,

where the diffuse attenuation of PAR with depth $(z)$ is due to the simulated Chl (kchl) $\left(\mathrm{m}^{-1}\right.$; Morel, 1988), water molecules $(\mathrm{kw})\left(0.04 \mathrm{~m}^{-1}\right.$; Morel, 1988) and nonchlorophyllous matter (knonchl). knonchl is set to $0.05 \mathrm{~m}^{-1}$ from 0 to $5 \mathrm{~m}$ depth to account for the release of optically active matter by melting sea ice observed during Malina (Doxaran et al., 2012) and to 0 below. $\mathrm{kchl}$ is calculated according to Morel et al. (1988) as follows:

$\mathrm{kchl}=0.0518 \mathrm{Chl}^{-0.572} \mathrm{Chl}$,

with

$\mathrm{Chl}=12\left(\frac{106}{16}\right)\left[\left(\frac{\mathrm{Chl}}{\mathrm{C}}\right)^{\mathrm{LP}} \mathrm{LP}+\left(\frac{\mathrm{Chl}}{\mathrm{C}}\right)^{\mathrm{SP}} \mathrm{SP}\right]$

Apart from grazing, phytoplankton loss terms include basal mortality and sinking for LP. LP sinking rates vary in the model from 0 to $0.075 \mathrm{~m} \mathrm{~d}^{-1}$ (e.g., Smith et al., 1991) 
depending on nutrient availability (Bienfang et al., 1983):

$\operatorname{sed}_{l p}=\operatorname{sed} \_p\left(1-\lim _{N}^{\mathrm{LP}}\right)$.

\section{A2 Zooplankton}

Mathematical formulations and parameters related to large zooplankton (LZ) dynamics were chosen to reflect copepods as they dominate in abundance at the study station (Forest et al., 2012). Grazing $\left(\mathrm{d}^{-1}\right)$ is described by an Ivlev function:

$G_{\mathrm{LZ}}=G_{\mathrm{LZ}}^{\max }\left[\left(1-e^{-\lambda(\mathrm{LP}+\mathrm{SZ})}\right)\right]$.

LZ grazes upon LP and protozooplankton (SZ) with a preyspecific grazing rate assumed to be proportional to the relative biomass of the prey (Campbell et al., 2009), defined for LP as follows:

$\mathrm{pf}_{\mathrm{LP}}=\frac{\mathrm{LP}}{\mathrm{LP}+\mathrm{SZ}}$.

Losses in LZ biomass are due to $\mathrm{NH}_{4}$ release, fecal pellet production (non-assimilated nitrogen ingested) and mortality. Mortality is assumed to be mainly due to predation (Eiane et al., 2002) and is described by a density-dependant quadratic function. The latter implicitly represents cannibalism as well as predation by appendicularians observed during the Malina cruise (Forest et al., 2012) and limits the occurrence of oscillations generated in such non-linear systems (Edwards and Bees, 2001). The constant of mortality is set to $0.2\left(\mathrm{mmol} \mathrm{N} \mathrm{m}^{-3}\right)^{-1}$ to simulate realistic mortality rates (e.g., Ohman et al., 2004).

SZ grazing upon SP and bacteria (BACT) is formulated by a sigmoid "Holling-type-III" function:

$G_{\mathrm{SZ}}=G_{\mathrm{SZ}}^{\max } \frac{(\mathrm{SP}+\mathrm{BACT})^{2}}{(\mathrm{SP}+\mathrm{BACT})^{2}+K_{G}^{2}}$.

The function provides a threshold-like limit for low SP biomass that enhances the biological system stability (e.g., Steele and Henderson, 1992). In polar waters, there is evidence that protozooplankton exert a control on small phytoplankton biomass only beyond a threshold (Lancelot et al., 1997). As for LZ, SZ graze upon both SP and BACT with a prey-specific grazing rate $\left(\mathrm{d}^{-1}\right)$ assumed to be proportional to the relative biomass of the prey, defined for SP as follows:

$\mathrm{pf}_{\mathrm{SP}}=\frac{\mathrm{SP}}{\mathrm{SP}+\mathrm{BACT}}$.

According to the study of Riegman et al. (1993), we set the fraction of food ingested by SZ and being converted into biomass to $30 \%$. Lehrter et al. (1999) report that $>30 \%$ of the total nitrogen release by SZ could be in the dissolved organic form. In the model, assuming that $30 \%$ is released as labile DON (dDONl), the remaining $70 \%$ are lost as $\mathrm{NH}_{4}$.
Remaining SZ loss terms are grazing by LZ and mortality. Similarly to LZ, mortality is expressed by a densitydependant quadratic function to represent grazing amongst SZ.

\section{A3 Bacteria}

Bacteria are explicitly simulated following the model of Fasham et al. (1990). dDON1 is the preferred substrate for bacterial uptake $\left(\mathrm{d}^{-1}\right)$ (Kirchman et al., 1989) represented by a Michaelis-Menten model:

Ubact $_{\mathrm{dDONl}}=\operatorname{Ubact}_{\max } \mathrm{BACT}\left(\frac{\mathrm{dDONl}}{K_{\mathrm{NH}_{4}, \mathrm{dDONl}}^{\mathrm{BAC}}+S+\mathrm{dDONl}}\right)$,

where Ubact $_{\text {max }}$ is the maximum uptake rate, $K_{\mathrm{NH}_{4}, \mathrm{dDON}}^{\mathrm{BACT}}$ $\left(\mathrm{mmol} \mathrm{N} \mathrm{m}^{-3}\right)$ the half-saturation constant for uptake and $S$ the total nitrogenous substrate $\left(\mathrm{mmol} \mathrm{N} \mathrm{m}^{-3}\right)$ defined as

$S=\left(\mathrm{NH}_{4}, 0.6 \mathrm{dDONl}\right)$.

Similarly, the uptake of $\mathrm{NH}_{4}$ is represented as follows:

Ubact $_{\mathrm{NH}_{4}}=\operatorname{Ubact}_{\max } \mathrm{BACT}\left(\frac{S}{K_{\mathrm{NH}_{4}, \mathrm{dDONI}}^{\mathrm{BACT}}+S+\mathrm{dDONl}}\right)$,

This formulation ensures that the uptake of $\mathrm{NH}_{4}$ will be 0.6 times the uptake of dDONl, as required by the balanced growth model (e.g., Fasham et al., 1990). Bacterial losses are in the $\mathrm{NH}_{4}$ form and represent $5 \%$ of the bacterial biomass.

\section{A4 Detritus}

The pool of detrital particulate organic nitrogen $(\mathrm{dPON})$ is fueled by LZ fecal pellet production and by LZ and LP mortality. The sedimentation loss term $\left(\mathrm{d}^{-1}\right)$ is expressed as a quadratic function allowing for increasing implicit aggregation of particles with increasing dPON concentrations:

$\operatorname{sed}_{\text {pon }}=$ sed_pondPON,

where sed_pon is the sedimentation constant $\left(\mathrm{md}^{-1}\right.$ $\left.\left(\mathrm{mmolN} \mathrm{m}^{-3}\right)^{-1}\right)$. The second loss term is the bacteriamediated dPON fragmentation into dDONl (Grossart and Ploug, 2001).

The dDON1 pool results from dPON fragmentation, SP and SZ mortality and SZ release. It is explicitly remineralized into $\mathrm{NH}_{4}$ by bacteria. Based on measurements made in the Beaufort Sea in summer and during the Malina cruise (Xie et al., 2012), we incorporated the photochemical production of $\mathrm{NH}_{4}$ from DONp (i.e., photoammonification process) $\left(\mathrm{mmol} \mathrm{N} \mathrm{m}^{-3} \mathrm{~d}^{-1}\right)$ within the first $10 \mathrm{~m}$ of the water column:

$\mathrm{ammo}=10 \frac{0.00006}{z} \mathrm{DONp}$. 
The mean constant rate for the June-August period was estimated to $\sim 0.00016 \mathrm{~d}^{-1}$. For mid-August, when the model is run, a value of $0.00006 \mathrm{~d}^{-1}$ is chosen to produce $\mathrm{NH}_{4}$ photoproduction rates comparable to those measured in late summer. Below $10 \mathrm{~m}$, the rate is set to 0 .

\section{A5 Nutrients}

$\mathrm{NH}_{4}$ resulting from bacterial remineralization and from DONp photoammonification, as well as from LZ and SZ release, fuels regenerated primary production and bacterial production. In turn, $\mathrm{NH}_{4}$ undergoes nitrification $\left(\mathrm{d}^{-1}\right)$ into $\mathrm{NO}_{3}$ as follows:

nitrif $=$ nitrif $_{\max }\left(\frac{\mathrm{NH}_{4}}{\mathrm{NH}_{4}+K_{\text {nitrif }}^{N}}\right)\left(1-\frac{E_{z}}{E_{z}+K_{\text {nitrif }}^{\text {light }}}\right)$,

where nitrif $_{\max }$ is the maximum nitrification rate and $K_{\text {nitrif }}^{N}$ and $K_{\text {nitrif }}^{\text {light }}$ the half-saturation constants for $\mathrm{NH}_{4}$ $\left(\mathrm{mmol} \mathrm{N} \mathrm{m}{ }^{-3}\right)$ and light $\left(\mathrm{E} \mathrm{m}^{-2} \mathrm{~d}^{-1}\right)$ use, respectively. The latter is defined as a fraction of surface $\operatorname{PAR}\left(E_{0}\right)$ as follows:

$K_{\text {nitrif }}^{\text {light }}=0.005 E_{0}$

Acknowledgements. VLF also acknowledges support from the European Space Agency and the Centre national d'études spatiales (CNES) as part of the MALINA project, funded by the Institut national des sciences de l'univers - Centre national de la recherche scientifique (CYBER/LEFE and PICS programmes), the Agence nationale de la recherche and the CNES. MB is supported by the Canada Excellence Research Chair in "Remote sensing of Canada's new Arctic frontier". HX is supported by the National Science and Engineering Research Council of Canada (NSERC). The authors wish to thank S. Bélanger, A. Forest, B. Gasser, Y. Gratton, S. Hooker, Y. Huot, J. C. Miquel and L. Prieur for having kindly provided data.

Edited by: S. Bélanger

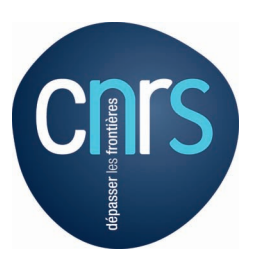

The publication of this article is financed by CNRS-INSU.

\section{References}

Ardyna, M., Gosselin, M., Michel, C., Poulin, M., and Tremblay, J.-É.: Environmental forcing of phytoplankton community structure and function in the Canadian High Arctic: contrasting oligotrophic and eutrophic regions, Mar. Ecol.-Prog. Ser., 442, 3757, 2011.
Ardyna, M., Babin, M., Gosselin, M., Devred, E., Bélanger, S., Matsuoka, A., and Tremblay, J.-É.: Parameterization of vertical chlorophyll a in the Arctic Ocean: impact of the subsurface chlorophyll maximum on regional, seasonal and annual primary production estimates, Biogeosciences Discuss., 10, 1345-1399, doi:10.5194/bgd-10-1345-2013, 2013.

Arrigo, K. R. and van Djiken, G. L.: Secular trends in Arctic Ocean net primary production, J. Geophys. Res., 116, C09011, doi:10.1029/2011JC007151, 2011.

Arrigo, K. R., van Dijken, G., and Pabi, S.: Impact of a shrinking Arctic ice cover on marine primary production, Geophys. Res. Lett., 35, L19603, doi:10.1029/2008GL035028, 2008.

Balzano, S., Marie, D., Gourvil, P., and Vaulot, D.: Composition of the summer photosynthetic pico and nanoplankton communities in the Beaufort Sea assessed by T-RFLP and sequences of the 18S rRNA gene from flow cytometry sorted samples, ISME J., 6 , 1480-1498, doi:10.1038/ismej.2011.213, 2012.

Bélanger, S., Babin, M., and Tremblay, J.-É.: Increasing cloudiness in Arctic damps the increase in phytoplankton primary production due to sea ice receding, Biogeosciences Discuss., 9, 1398714012, doi:10.5194/bgd-9-13987-2012, 2012.

Bienfang, P., Szyper, J., and Laws, E.: Sinking rate and pigment responses to light limitation of a marine diatom: implications to dynamics of chlorophyll maximum layers, Oceanologica Ac. 6, 55-62, 1983.

Booth, B. C. and Horner, R. A.: Microalgae on the Arctic Ocean Section, 1994: species abundance and biomass, Deep-Sea Res Pt. II, 44, 1607-1622, 1997.

Bushaw, K. L., Zepp, R. G., Tarr, M. A., Schultz-Jander, D., Bourbonniere, R. A., Hodson, R. E., Miller, W. L., Bronk, D. A., and Moran, M. A.: Photochemical release of biologically available nitrogen from aquatic dissolved organic matter, Nature, 381, 404-407, 1996.

Campbell, R. G., Sherr, E. B., Ashjian, C. J., Plourde. S., Sherr, B. F., Hill, V., and Stockwell, D. A.: Mesozooplankton prey preference and grazing impact in the western Arctic Ocean, DeepSea Res. Pt. II, 56, 1274-1289, doi:10.1016/j.dsr2.2008.10.027, 2009.

Claustre, H., Morel, A., Babin, M., Cailliau, C., Marie, D., Marty, J.-C., and Vaulot, D.: Variability in particle attenuation and stimulated fluorescence in the tropical and equatorial Pacific: scales, patterns and some biogeochemical implications, J. Geophys. Res., 104, 3401-3422, 1999.

Cloern, J. E., Grenz, C., and Videgar-Lucas, L.: An empirical model of the phytoplankton chlorophyll:carbon ratio - the conversion factor between productivity and growth rate, Limnol. Oceanogr., 40, 1313-1321, 1995.

Comiso, J. C., Parkinson, C. L., Gersten, R., and Stock. L.: Accelerated decline in the Arctic sea ice cover, Geophys. Res. Lett., 35, L01703, doi:10.1029/2007GL031972, 2008.

Dorch, Q.: The interaction between ammonium and nitrate uptake in phytoplankton, Mar. Ecol.-Prog. Ser., 61, 183-201, 1990.

Doxaran, D., Ehn, J., Bélanger, S., Matsuoka, A., Hooker, S., and Babin, M.: Optical characterisation of suspended particles in the Mackenzie River plume (Canadian Arctic Ocean) and implications for ocean colour remote sensing, Biogeosciences, 9, 32133229, doi:10.5194/bg-9-3213-2012, 2012.

DuRand, M. D., Green, R. E., Sosik, H. M., and Olson, R. J.: Diel variations in Optical properties of Micromonas pusilla (Prasino- 
phyceae), J. Phycol., 38, 1132-1142, 2002.

Edwards, A. M. and Bees, M. A.: Generic dynamics of a simple plankton population model with a non-integer exponent of closure, Chaos Solitons Fractals, 12, 289-300, 2001.

Eiane, K., Aksnes, D. L., Ohman, M. D., Wood, S., and Martinussen, M. B.: Stage-specific mortality of Calanus spp. under different predation regimes, Limnol. Oceanogr., 47, 636-645, 2002.

Fasham, M. J. R., Ducklow, H. W., and McKelvie, S. M.: A nitrogen-based model of plankton dynamics in the oceanic mixed layer, J. Mar. Res., 48, 591-639, 1990.

Forest, A., Galindo, V., Darnis, G., Pineault, S., Lalande, C., Tremblay, J.-É., and Fortier, L.: Carbon biomass, elemental ratios $(\mathrm{C}: \mathrm{N})$ and stable isotopic composition $(\delta 13 \mathrm{C}, \delta 15 \mathrm{~N})$ of dominant calanoid copepods during the winter-to-summer transition in the Amundsen Gulf (Arctic Ocean), J. Plankton. Res., 33, 161$178,2010$.

Forest, A., Stemmann, L., Picheral, M., Burdorf, L., Robert, D., Fortier, L., and Babin, M.: Size distribution of particles and zooplankton across the shelf-basin system in southeast Beaufort Sea: combined results from an Underwater Vision Profiler and vertical net tows, Biogeosciences, 9, 1301-1320, doi:10.5194/bg-91301-2012, 2012.

Geider, R. J., MacIntyre, H. L., and Kana, T. M.: Dynamic model of phytoplankton growth and acclimation: responses of the balanced growth rate and the chlorophyll a: carbon ratio to light, nutrient-limitation and temperature. Mar. Ecol.-Progr. Ser., 148, 187-200, 1997.

Grossart, H.-P. and Ploug, H.: Microbial degradation of organic carbon and nitrogen on diatom aggregates, Limnol. Oceanogr., 46, 267-277, 2001.

Holmes, M. R., Aminot, A., Kerouel, R., Hooker, B. A., and Peterson, J. B.: A simple and precise method for measuring ammonium in marine and freshwater ecosystems, Can. J. Fish Aquat. Sci., 56, 1801-1808, 1999.

Hooker, S. B., Morrow, J. H., and Matsuoka, A.: The $1 \%$ and $1 \mathrm{~cm}$ perspective in deriving and validating AOP data products, Biogeosciences Discuss., 9, 9487-9531, doi:10.5194/bgd-9-94872012, 2012.

Huot, Y., Babin, M., and Bruyant, F.: Photosynthetic parameters in the Beaufort Sea in relation to the phytoplankton community structure, Biogeosciences, 10, 3445-3454, doi:10.5194/bg10-3445-2013, 2013.

Kahru, M., Brotas, V., Manzano-Sarabia, M., and Mitchell, B. G.: Are phytoplankton blooms occurring earlier in the Arctic? Glob. Change Biol., 17, 1733-1739, doi:10.1111/j.13652486.2010.02312.x, 2011.

Kirchman, D. L., Kiel, R. G., and Wheeler, P. A.: The effect of amino acids on ammonium utilization and regeneration by heterotrophic bacteria in the subarctic Pacific, Deep-Sea Res., 36, 1763-1776, 1989.

Kirchman, D. L., Hill, V., Cottrell, M. T., Gradinger, R., Malmstrom, R. R., and Parker, A.: Standing stocks, production, and respiration of phytoplankton and heterotrophic bacteria in the western Arctic Ocean, Deep-Sea Res. Pt. II, 56, 1237-1248, doi:10.1016/j.dsr2.2008.10.018, 2009.

Lancelot, C., Becquevort, S., Menon, P., Mathot, S., and Dandois J.-M.: Ecological modelling of the planktonic microbial foodweb, in Belgian Research Program on the Antarctic, Scientific Results of Phase III (1992-1996): Marine Biogeochemistry and
Ecodynamics, edited by: Caschetto. S., 1, 1-78, Fed. Off. for Sci., Tech. and Cult. Affairs, Brussels, 1997.

Le Fouest, V., Postlethwaite, C., Morales Maqueda, M. A., Bélanger, S., and Babin, M.: On the role of tides and strong wind events in promoting summer primary production in the Barents Sea, Cont. Shelf Res., 31, 1869-1879, doi:10.1016/j.csr.2011.08.013, 2011.

Lehrter, J. C., Pennock, J. R., and McManus. G. B.: Microzooplankton grazing and nitrogen excretion across a surface estuarinecoastal interface, Estuaries, 22, 113-125, 1999.

Li, W. K. W., McLaughlin, F. A., Lovejoy, C., and Carmack, E. C.: Smallest algae thrive as the Arctic Ocean freshens, Science, 326, 539, doi:10.1126/science.1179798, 2009.

MacIntyre, H. L., Kana, T. M., Anning, T., and Geider, R. J.: Photoacclimation of photosynthesis irradiance response curves and photosynthetic pigments in microalgae and cyanobacteria, J. Phycology, 38, 17-38, 2002.

Martin, J., Tremblay, J.-É., Gagnon, J., Tremblay, G., Lapoussière, A., Jose, C., Poulin, M., Gosselin, M., Gratton, Y., and Michel, C.: Prevalence, structure and properties of subsurface chlorophyll maxima in Canadian Arctic waters, Mar. Ecol.-Prog. Ser., 42, 69-84, doi:10.3354/meps08666, 2010.

Matrai, P., Vernet, M., and Wassmann, P.: Relating temporal and spatial patterns of DMSP in the Barents Sea to phytoplankton biomass and productivity, J. Marine Syst., 67, 83-101, doi:10.1016/j.jmarsys.2006.10.001, 2007.

Morel, A.: Optical modeling of the upper ocean in relation to its biogenous matter content (case I waters), J. Geophys. Res., 93, 10749-10768, 1988.

Morell, J. and Corredor, J.: Photomineralization of fluorescent dissolved organic matter in the Orinoco River plume: Estimation of ammonium release, J. Geophys. Res., 106, 16807-16813, doi:10.1029/1999JC000268, 2001.

Ohman, M. D., Eiane, K., Durbin, E. G., Runge, J. A., and Hirche, H.-J.: A comparative study of Calanus finmarchicus mortality patterns at five localities in the North Atlantic, ICES J. Mar. Sci., 61, 687-697, 2004.

O’Neill, R. V., DeAngelis, D. L., Pastor, J. J., Jackson, B. J., and Post, W. M.: Multiple nutrient limitations in ecological models, Ecol. Model., 46, 147-163, 1989.

Ortega-Retuerta, E., Jeffrey, W. H., Babin, M., Bélanger, S., Benner, R., Marie, D., Matsuoka, A., Raimbault, P., and Joux, F.: Carbon fluxes in the Canadian Arctic: patterns and drivers of bacterial abundance, production and respiration on the Beaufort Sea margin, Biogeosciences, 9, 3679-3692, doi:10.5194/bg-9-36792012, 2012a.

Ortega-Retuerta, E., Jeffrey, W. H., Ghiglione, J.-F., and Joux, F.: Evidence of heterotrophic prokaryotic activity limitation by nitrogen in the Western Arctic Ocean during summer, Polar Biol., 35, 785-794, 2012b.

Osborn, T. R.: Estimates of the local rate of vertical diffusion from dissipation measurements, J. Phys. Oceanogr., 10, 83-89, 1980.

Para, J., Charrière, B., Matsuoka, A., Miller, W. L., Rontani, J. F., and Sempéré, R.: UV/PAR radiation and DOM properties in surface coastal waters of the Canadian shelf of the Beaufort Sea during summer 2009, Biogeosciences, 10, 2761-2774, doi:10.5194/bg-10-2761-2013, 2013.

Popova, E. E., Yool, A., Coward, A. C., Aksenov, Y. K., Alderson, S. G., de Cuevas, B. A., and Anderson, T. R.: Control of primary 
production in the Arctic by nutrients and light: insights from a high resolution ocean general circulation model, Biogeosciences, 7, 3569-3591, doi:10.5194/bg-7-3569-2010, 2010.

Raimbault, P., Slawyk, G., Coste, B, and Fry, J.: Feasibility of using an automated colorimetric procedure for the determination of seawater nitrate in the 0 to $100 \mathrm{nM}$ range: Examples from field and culture, Mar. Biol., 104, 347-351, 1990.

Raimbault, P., Slawyk, G., Boudjellal, B., Coatanoan, C., Conan, P., Coste, B., Garcia, N., Moutin, T., and Pujo-Pay, M.: Carbon and nitrogen uptake and export in the equatorial pacific at $150^{\circ}$ W: Evidence of an efficient regenerated production cycle, J. Geophys. Res., 104, 3341-3356, 1999a.

Raimbault, P., Diaz, F., and Boudjellal, B.: Simultaneous determination of particulate forms of carbon, nitrogen and phosphorus collected on filters using a semi-automatic wet-oxidation procedure, Mar. Ecol.-Prog. Ser., 180, 289-295, 1999b.

Redfield, A. C., B. H., Ketchum, and Richards, F. A.: The influence of organisms on the composition of sea water, in: The Sea: Ideas and Observations on Progress in the Study of the Seas, edited by: Hill, M. N., 26-27, Wiley-Intersci., Hoboken, NY, 1973.

Reigstad, M., Wassmann, P., Wexels Riser, C., Øygarden, S., and Rey, F.: Variations in hydrography, nutrients and chlorophyll a in the marginal ice-zone and the central Barents Sea, J. Marine Syst., 38, 9-29, doi:10.1016/S0924-7963(02)00167-7, 2002.

Riegman, R., Kuipers, B. R., Nooedeloos, A. A. M., and Witte, H. J.: Size-differential control of phytoplankton and the structure of plankton communities, Neth. J. Sea Res., 31, 255-265, 1993.

Roach, P. J.: Computational fluid dynamics, 446 pp., Hermosa, Albuquerque, N. M., 1972.

Sakshaug, E.: Primary and secondary production in the Arctic seas, in: he organic carbon cycle in the Arctic Ocean, edited by: Stein, R. and MacDonald, R. W., T, Springer-Verlag, Berlin, 57-81, 2004.

Sherr, E. B., Sherr, F. B., Wheeler, P. A., and Thompson, K.: Temporal and spatial variation in stocks of autotrophic and heterotrophic microbes in the upper water column of the central Arctic Ocean, Deep-Sea Res. Pt. I, 50, 557-571, doi:10.1016/S0967-0637(03)00031-1, 2003.

Sibert, V., Zakardjian, B., Gosselin, M., Starr, M., Senneville, S., and LeClainche, Y.: 3D bio-physical model of the sympagic and planktonic productions in the Hudson Bay System, J. Marine Syst. 88, 401-422, doi:10.1016/j.jmarsys.2011.03.014, 2011.

Slagstad, D., Ellingsen, I. H., and Wassmann, P.: Evaluating primary and secondary production in an Arctic Ocean void of summer sea ice: an experimental simulation approach, Prog. Oceanogr., 90, 117-131. doi:10.1016/j.pocean.2011.02.009, 2011.

Smith, Jr., W. O., Kelly, H. P., and Vogelin, D.: Phytoplankton sinking rates in the Ross Sea, Antarctic J. US, 151-152, 1991.

Steele, J. H. and Henderson, E. W.: The role of predation in plankton models, J. Plankton Res., 14, 157-172, 1992.

Tank, S. E., Manizza, M., Holmes, R. M., McClelland, J. W., and Peterson, B. J.: The processing and impact of dissolved riverine nitrogen in the Arctic Ocean, Estuar. Coasts, doi:10.1007/s12237-011-9417-3, 35, 401-415, 2012.
Tremblay, J.-É and Gagnon, J.: The effects of irradiance and nutrient supply on the productivity of Arctic waters: a perspective on climate change, in: Influence of climate change on the changing Arctic and Subarctic conditions, edited by: Nihoul, J. C. J. and Kostianoy, A. G., NATO Science for Peace and Security SeriesC: Environmental Security, 73-93, 2009.

Tremblay, J.-É., Legendre, L., Klein, B., and Therriault, J.-C.: Size differential uptake of nitrogen and carbon in a marginal sea (Gulf of St. Lawrence, Canada): Significance of diel periodicity and urea uptake, Deep Sea Res. Pt. II, 47, 489-518, 2000.

Tremblay J.-É., Simpson, K., Martin, J., Miller, L., Gtatton, Y., Barber, D., and Price, N. M.: Vertical stability and the annual dynamics of nutrients and chlorophyll fluorescence in the coastal, southeast Beaufort Sea, J. Geophys. Res., 113, C07S90, doi:10.1029/2007JC004547, 2008.

Tremblay, J.-É., Raimbault, P., Garcia, N., and Gagnon, J.: Distribution of nutrients and organic carbon, nitrogen and phosphorus in the southeast Beaufort Sea: implications for primary, in preparation, Biogeosciences Discuss, 2013.

Vähätalo, A. V., Aarnos, H., Hoikkala, L., and Lignell, R.: Photochemical transformation of terrestrial dissolved organic matter supports hetero- and autotrophic production in coastal waters, Mar. Ecol.-Prog. Ser., 423, 1-14, doi:10.3354/meps09010, 2011.

Walsh, J. J., A. Dieterle, D. A., Chen, R., Lenes, J. M., Maslowski, W., Cassano, J. J., Whitledge, T. E., Stockwell, D., Flint, M., Sukhanova, I. N., and Christensen, J.: Trophic cascades and future harmful algal blooms within ice-free Arctic Seas north of Bering Strait: A simulation analysis, Prog. Oceanogr., 91, 312343, doi:10.1016/j.pocean.2011.02.001, 2011.

Wassmann, P. and Reigstad, M.: Future Arctic Ocean seasonal ice zones and implications for pelagic-benthic coupling, Oceanography, 24, 220-231, doi:10.5670/oceanog.2011.74, 2011.

Xie, H., Bélanger, S., Song, G., Benner, R., Taalba, A., Blais, M., Tremblay, J.-É., and Babin, M.: Photoproduction of ammonium in the southeastern Beaufort Sea and its biogeochemical implications, Biogeosciences, 9, 3047-3061, doi:10.5194/bg-9-30472012, 2012.

Zakardjian, B. A. and Prieur, L.: A numerical study of primary production related to vertical mixing with special reference to vertical motions of phytoplankton cells in nutrient and light fields, J. Marine Syst., 5, 267-295, 1994.

Zakardjian, B. and Prieur, L.: Biological and chemical signs of upward motions in permanent geostrophic fronts of the Western Mediterranean, J. Geophys. Res., 103, 27849-27866, doi:10.1029/98JC01537, 1998.

Zhang, J., Spitz, Y. H., Steele, M., Ashjian, C., Campbell, R., Berline L., and Matrai, P.: Modeling the impact of declining se ice on the Arctic marine planktonic ecosystem, J. Geophys. Res., 115, C10015, doi:10.1029/2009JC005387, 2010. 